\title{
Ophicarbonate evolution from seafloor to subduction and implications for deep-Earth $\mathrm{C}$ cycling
}

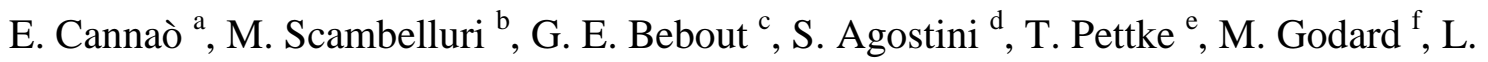 \\ Crispini $^{b}$ \\ a Dipartimento di Scienze della Terra “A. Desio”, Università di Milano, Via Botticelli 23, \\ 21133 Milano, Italy \\ ${ }^{b}$ Dipartimento di Scienze della Terra, dell'Ambiente e della Vita, Università di Genova, C.so \\ Europa 26, 16132 Genova, Italy \\ ${ }^{c}$ Department of Earth and Environmental Sciences, Lehigh University, Bethlehem, PA 18015, \\ USA \\ ${ }^{d}$ Istituto di Geoscienze e Georisorse, CNR, Via Moruzzi 1, 56124 Pisa, Italy \\ ${ }^{e}$ Institute of Geological Sciences, University of Bern, 1+3 Baltzerstrasse, CH-3012, Bern, \\ Switzerland \\ ${ }^{f}$ Geosciences Montpellier, CNRS, Universite de Montpellier, Place Eugene Bataillon, 34095 \\ Montpellier, France
}




\section{1}

\section{Abstract}

The chemical and physical processes operating during subduction-zone metamorphism can profoundly influence the cycling of elements on Earth. Deep-Earth carbon (C) cycling and mobility in subduction zones has been of particular recent interest to the scientific community. Here, we present textural and geochemical data (C-O, Sr isotopes and bulk and in-situ trace element concentrations) for a suite of ophicarbonate rocks (carbonate-bearing serpentinites) metamorphosed over a range of peak pressure-temperature $(P-T)$ conditions together representing a prograde subduction zone $P-T$ path. These rocks, in order of increasing peak $P-T$ conditions, are the Internal Liguride ophicarbonates (from the Bracco unit, N. Apennines), pumpellyite- and blueschist-facies ophicarbonates from the Voltri Massif (W. Ligurian Alps) and the Queyras (W. Alps), respectively, and eclogite-facies ophicarbonates from the Voltri Massif. The Bracco oceanic ophicarbonates retain breccia-like textures associated with their seafloor hydrothermal and sedimentary origins. Their trace element concentrations and $\delta^{18} \mathrm{O}_{\text {VSMOW }}(+15.6$ to $+18.2 \%), \delta^{13} \mathrm{C}_{\mathrm{VPDB}}(+1.1$ to $+2.5 \%)$ and their ${ }^{87} \mathrm{Sr} /{ }^{86} \mathrm{Sr}(0.7058$ to 0.7068$)$, appear to reflect equilibration during Jurassic seawater-rock interactions. Intense shear deformation characterizes the more deeply subducted ophicarbonates, in which prominent calcite recrystallization and carbonation of serpentinite clasts occurred. The isotopic compositions of the pumpellyite-facies ophicarbonates overlap those of their oceanic equivalents whereas the most deformed blueschist-facies sample shows enrichments in radiogenic $\mathrm{Sr}\left({ }^{87} \mathrm{Sr} /{ }^{86} \mathrm{Sr}=0.7075\right.$ ) and depletion in ${ }^{13} \mathrm{C}$ (with $\delta^{13} \mathrm{C}$ as low as 2.0\%o). These differing textural and geochemical features for the two suites reflect interaction with fluids in closed and open systems, respectively. The higher- $P$-metamorphosed ophicarbonates show strong shear textures, with coexisting antigorite and dolomite, carbonate veins crosscutting prograde antigorite foliation and, in some cases, relics of magnesitenodules enclosed in the foliation. These rocks are characterized by lower $\delta^{18} \mathrm{O}(+10.3$ to 13.0\%o), enrichment in radiogenic $\mathrm{Sr}\left({ }^{87} \mathrm{Sr} /{ }^{86} \mathrm{Sr}\right.$ up to 0.7096) and enrichment in incompatible 
and fluid-mobile element (FME; e.g., As, $\mathrm{Sb}, \mathrm{Pb}$ ). These data seemingly reflect interaction

28 with externally-derived metamorphic fluids and the infiltrating fluids likely were derived 29 from dehydrating serpentinites with hybrid serpentinite-sediment compositions. The 30 interaction between these two lithologies could have occurred prior to or after dehydration of

31 the serpentinites. We suggest that decarbonation and dissolution/precipitation processes 32 operating in ancient subduction zones, and resulting in the mobilization of $\mathrm{C}$, are best traced 33 by a combination of detailed field and petrographic observations, $\mathrm{C}, \mathrm{O}$ and $\mathrm{Sr}$ isotope 34 systematics (i.e., 3D isotopes), and FME inventories. Demonstration of such processes is key

\section{Introduction}

Ophicarbonates (i.e., carbonated ultramafic rocks) are potentially important carbon (C) reservoirs influencing the long-term $\mathrm{C}$ cycle in the solid Earth. Large volumes of ophicarbonate form by peridotite alteration at the seafloor, causing low- to moderatetemperature $(T)$ serpentinization (e.g., Mével, 2003; O’Hanley, 1996) and carbonation by mixed seawater and alkaline hydrothermal fluids (e.g., Lost City hydrothermal fields, FrühGreen et al., 2004; Kelley et al., 2005; Ludwig et al., 2006). Ophicarbonates display brecciated textures consisting of serpentinite clasts enclosed by sets of carbonate veins and/or by a micrite matrix. Such rocks occur in present-day oceans (e.g., the Atlantic; Bonatti, 1976) and their abundance in ophiolitic complexes documents ophicarbonate formation also in ancient oceans (e.g., Früh-Green et al., 1990; Schwarzenbach et al., 2013; Tartarotti et al., 
2019; Weissert and Bernoulli, 1984). Ophicarbonates can also form at depth in subduction

54 zones via interaction of (meta)serpentinite with carbonic fluids leading to carbonation of rock55 forming silicates and to $\mathrm{C}$ sequestration into oceanic slabs and supra-subduction mantle 56 (Piccoli et al., 2016; Scambelluri et al., 2016). These two processes together affect C storage and transport from oceans to subduction zones and the transfer of $\mathrm{C}-\mathrm{O}-\mathrm{H}$ fluids into volcanic arcs (Alt et al., 2013; Collins et al., 2015; Kerrick and Connolly, 1998; Scambelluri et al., 2016) or in deeper parts of the mantle.

Experiments and thermodynamic modelling suggest relative immobility of $\mathrm{C}$ in subducting oceanic crustal rocks to very high pressure-temperatures $(P-T)$ conditions unless the rocks are infiltrated by $\mathrm{H}_{2} \mathrm{O}$-rich fluids (Collins et al., 2015; Kerrick and Connolly, 2001, 1998; Molina and Poli, 2000; Poli et al., 2009). Studies of exposed high- $P / T$ metamorphic rocks document some $\mathrm{C}$ mobilization during subduction either by decarbonation reactions or by carbonate dissolution in aqueous fluids (Ague and Nicolescu, 2014; Cook-Kollars et al., 2014; Frezzotti et al., 2011; Malaspina et al., 2009; Piccoli et al., 2016; Sapienza et al., 2009; Scambelluri et al., 2016); however, the scale of this related $\mathrm{C}$ transport has remained unclear (see the discussion by Epstein et al. 2019). Field and stable isotope studies of high- $P$ and ultrahigh-pressure $(U H P)$ metamorphic suites indicate that the extent of $\mathrm{C}$ mobilization by these processes is highly dependent upon the degree to which rocks behave as systems open to infiltration by externally-derived $\mathrm{H}_{2} \mathrm{O}$-rich fluids (Collins et al., 2015; Epstein et al., 2019).

Serpentinite is pivotal in the subduction zone $\mathrm{C}$ cycle because, as the result of antigorite dehydration, it supplies $\mathrm{H}_{2} \mathrm{O}$ to adjacent carbonate rocks, thus potentially driving decarbonation reactions (i.e., destabilization of carbonates) and carbonate dissolution. Moreover, serpentine is reactive to $\mathrm{C}-\mathrm{O}-\mathrm{H}$ fluids and sequesters $\mathrm{CO}_{2}$ from fluids via carbonation of its silicate minerals (Scambelluri et al., 2016). The study of ophicarbonates is timely, given recent interest in subduction zone $\mathrm{C}$ cycling, and can address the mechanisms of 
C-storage and loss within a single, complex rock system and between serpentinite and 79 carbonate-bearing reservoirs.

80 Abundant petrographic and petrologic work available to date deals with present-day and 81 fossil oceanic ophicarbonate rocks (Bonatti, 1976; Clerc et al., 2014; Collins et al., 2015; 82 Cortesogno et al., 1980; Driesner, 1993; Galli and Togliatti, 1965; Lafay et al., 2017; Treves 83 et al., 1995; Weissert and Bernoulli, 1984); however, less attention has been paid to 84 ophicarbonate evolution during subduction-zone metamorphism (Collins et al., 2015; Debret 85 et al., 2018; Driesner, 1993; Scambelluri et al., 2016). We focused on ophicarbonates exposed 86 in Alpine-Apennine ophiolite sequences representing a wide range of peak metamorphic $P-T$, 87 from low- $T$ oceanic conditions recorded by Apennine ophicarbonates, to pumpellyite-, 88 blueschist- and eclogite-facies conditions experienced by ophicarbonates from the Ligurian 89 and the Western Alps. In this paper, based on study of high- $P$ metamorphic rocks, we 90 demonstrate that decarbonation and dissolution/precipitation processes operating in ancient 91 subduction zones are best traced by a combination of detailed field and petrographic 92 observations, FME inventories, and C, O, and $\mathrm{Sr}$ isotope systematics (i.e., 3D isotopes).

94 2. Geological setting

\subsection{Northern Ligurian Apennine ophicarbonates}

In the Northern Ligurian Apennine, ophiolites either occur as large olistoliths (in the 98 sedimentary flysch of the External Liguride Units) or form large coherent bodies (in the 99 Internal Liguride Units). In the latter setting, ophicarbonates (Fig. 1A) occur at the 
oceanic sediments (Alt et al., 2018; Decandia et al., 1998; Lagabrielle, 1987). Thus far,

tectonic (OCI) and sedimentary (OCII) ophicarbonates have been distinguished based on textural and petrographic features (e.g., Lemoine et al., 1987). The OCI type is characterized by polyphase brittle-ductile to brittle deformation (Treves and Harper, 1994). These rocks display early serpentine formation after mantle minerals and in shear extensional veins, followed by infiltration of $\mathrm{CO}_{2}$-rich fluids to form a sequence of generations of calcite veins in response to increasing hydrothermal fluid pressure $\left(\mathrm{P}_{\text {fluid }} / \mathrm{P}_{\text {lithostatic }}>1\right)$. The last brittle deformation led to formation of veins filled by calcite and talc druses (Treves and Harper, 1994). The set of tectonic and hydrothermal structures recorded by the OCI is related to the tectonic exposure of the oceanic mantle at surface levels under progressively lower temperature conditions at extensional core-complexes at slow-spreading ridges. The OCI samples are thus representative of extensional fault settings (Treves and Harper, 1994) and are comparable with ophicarbonates beneath the Lost City hydrothermal vent at the Mid-Atlantic Ridge (e.g., Ludwig et al., 2006). Tectonic-sedimentary reworking of the exposed 118 serpentinized mantle, coupled with calcite precipitation, leads to the formation of OCII 119 showing angular to sub-angular serpentinite clasts of varying sizes embedded in a micrite 120 sedimentary matrix (Treves and Harper, 1994). Oxidation and carbonation processes accompany the hydrothermal alteration, allowing formation of hematite and thus conferring upon these rocks a typical red color during a process thought to have generated the Ligurian ophicarbonate variety know as Rosso di Levanto (Galli, 1957).

\subsection{Western Alps}

The Alpine architecture consists of large tectonic units of continental and oceanic 127 affinity (e.g., Dal Piaz et al., 2003): the ophicarbonate rocks studied here belong to the 128 oceanic lithosphere exposed at three main localities of the Upper Penninic nappe stack and 129 recording progressively higher peak metamorphic $P-T$ during subduction (Fig. 1). From lower 
to higher grade, the sampled localities are: the pumpellyite-actinolite facies Sestri-Voltaggio

Zone (Ligurian Alps), the blueschist-facies Queyras (Ubaye locality; French Alps), and the eclogite-facies-metamorphosed Voltri Massif (Ligurian Alps).

\subsubsection{Sestri-Voltaggio zone}

The Sestri-Voltaggio zone consists of several tectonic units and is believed to represent the N-S junction zone between the Alpine chain and the Northern Apennines (Crispini and Capponi, 2001). The ophicarbonate rocks sampled in this area belong to the Figogna unit, consisting of oceanic lithospheric mantle comparable to that in the Voltri Massif, but which escaped eclogite facies metamorphism during Alpine subduction. The metamorphic grade of this unit is pumpellyite-actinolite facies, in the stability field of lawsonite $\left(270-320{ }^{\circ} \mathrm{C}\right.$ and 0.6 GPa; Leoni et al., 1996). Here ophicarbonates crop out near the village of Pietralavezzara in decametric-sized slices with N-S orientations (PL samples in Fig. 1C). Despite the polyphase deformation that affected the Figogna unit, the original oceanic sequence showing ophicarbonates on top of the ultramafic and gabbroic basement, and below a volcanosedimentary cover, can still be recognized (Crispini and Capponi, 2001).

\subsubsection{Queyras complex}

The Queyras complex is part of the Piedmont-Ligurian domain, west of the eclogite149 facies Monviso ophiolite and near the contact with the Brianconnais domain (Fig. 1B). This 150 complex was interpreted as a sedimentary accretionary wedge composed of oceanic sediments 151 and accreted slices of oceanic lithosphere (Lafay et al., 2013; Lagabrielle et al., 1985). The 152 metamorphic grade increases eastwards, from temperature $<350{ }^{\circ} \mathrm{C}$ and pressure $<1.1 \mathrm{GPa}$, 153 to $P-T$ conditions pertaining to the blueschist-facies conditions (up to $480{ }^{\circ} \mathrm{C}$ and $\mathrm{P}>1.2$ 154 GPa; Agard et al., 2001). The Queyras ophiolite crops out as scattered large olistoliths within 155 the metasedimentary Schistes Lustrés: the ophiolite bodies preserve the original internal 
structure and stratigraphy, enabling reconstruction of their oceanic history (Tricart and

Lemoine, 1991). Within each body, three major components of the oceanic lithosphere can be distinguished; from bottom to top these are (i) an ultramafic sequence of serpentinized mantle-derived peridotites, locally crosscut by Late Triassic gabbro intrusions (Carpena and Caby, 1984), (ii) a discontinuous basaltic layer of tholeiitic pillow basalts, and (iii) a sedimentary pelagic cover represented by the Schists Lustrés complex. Where the basaltic sequence is missing, the ultramafic and the sedimentary rocks can be directly in contact (Tricart and Lemoine, 1991). The ophicarbonate rocks are on top of the ultramafic sequence and can be subdivided into groups of tectonic (OCI) and sedimentary (OCII) origin. The first type is characterized by a dense network of calcite veins and fractures formed by tectonic extension and hydraulic fracturing; the OCII type derives from in-situ reworking of OCI, of serpentinites and/or basaltic materials forming clasts in a micrite matrix (e.g., Lemoine et al., 1987). The presence of ophicarbonate rocks is interpreted as representing exposure of mantle to seawater on the ocean floor (Tricart and Lemoine, 1991). The ophicarbonate samples analyzed in this study (CU samples in Fig. 1B) experienced blueschist-facies $P-T$ conditions (325 - $375{ }^{\circ} \mathrm{C}$ and 1.1 - 1.4 GPa; Michard et al., 2004).

\subsubsection{Voltri Massif}

The ophiolitic Voltri Massif is a blueschist- to eclogite-facies complex of Jurassic 175 oceanic lithosphere composed of serpentinites hosting gabbro- and basalt-derived eclogite and 176 metarodingite. This sequence is associated with high- $P$-metamorphosed oceanic sediment, i.e. 177 calc- and mica-schists (referred to as Schistes Lustrés) interlayered with metabasalts and 178 cherts (e.g., Chiesa et al., 1975). Remnants of sub-continental lithospheric mantle are well179 exposed in the Erro-Tobbio metaperidotite unit, representing the pre-Alpine rifting and ocean180 floor alteration followed by subduction and metamorphism at eclogite-facies $P-T$ conditions 181 (Hermann et al., 2000; Hoogerduijn Strating et al., 1993; Scambelluri et al., 1995, 1991; 
182

Vissers et al., 1995, 1991). Peak metamorphic $P-T$ estimates for the Voltri Massif are about $450-500{ }^{\circ} \mathrm{C}$ and $1.3-1.7 \mathrm{GPa}$ (Cimmino et al., 1979; Federico et al., 2004; Messiga and Scambelluri, 1991), conditions that produced metamorphic olivine + antigorite in serpentinites, garnet + omphacite + rutile in eclogite and high-Si-bearing phengite + garnet in metasedimentary rocks. Field and geochemical evidence (Cannaò et al., 2016; Federico et al., 2007; Scambelluri and Tonarini, 2012), together with numerical modelling (Malatesta et al., 2012), suggests a complex history for the Voltri Massif during prograde and retrograde evolution along the slab-mantle interface.

The ophicarbonate rocks of the Voltri Massif crop out in several localities (Fig. 1) and were first described by Cortesogno et al. (1981, 1980). These rocks consist of carbonate mineral phases (calcite, dolomite and/or magnesite) coexisting with antigorite and, locally, metamorphic olivine. These rocks are interpreted as the metamorphic counterparts in the nonsubducted oceanic ophicarbonates of the Northern Apennines ophiolites, with grades ranging from greenschist-, to blueschist-, to eclogite-facies. Recently, Scambelluri et al. (2016) described in detail the evolution, metamorphic reactions, and $\mathrm{C}$ and $\mathrm{O}$ isotope compositions at an outcrop within the Voltri Massif, highlighting the high potential of serpentinite for sequestering $\mathrm{C}$ and thus influencing the deep $\mathrm{C}$ cycle. The samples from the Voltri Massif analyzed in this study are from two localities representing ophicarbonates affected by the eclogite-facies metamorphism: La Pesca (Scambelluri et al., 2016; LP13 EOC samples) and Sant'Anna (SA samples).

\section{Petrography and microstructures}

The ophicarbonate samples presented here retain evidence of complex polyphase histories. Here, we describe the key features of representative ophicarbonate samples from each locality: for the Northern Apennine, we retain the classification of the ophicarbonates of tectonic-hydrothermal (OCI) and sedimentary (OCII) origin initially proposed by Lemoine et 
al. (1987). Also, we describe the oceanic serpentinite exposed in the Northern Apennine,

\subsection{Oceanic Northern Apennine Ophicarbonates}

\section{Serpentinite protolith rocks}

The ultramafic protoliths of the oceanic ophicarbonates are represented by highly (90\%) to fully $(100 \%)$ serpentinized mantle peridotites. In these rocks, static pseudomorphic replacement led to formation of mesh serpentine + magnetite textures after mantle olivine and bastite after mantle pyroxenes in which traces of the former pyroxene cleavage are still recognizable. The medium grain size of the pseudomorphs and the isotropic texture suggest an original harzburgite for these ultramafic rocks. The sample collected in this study does not display evidence for deformation, but high- $T$ shear domains are described in the literature for the serpentinite basement (Treves and Harper, 1994).

\section{Ophicarbonates of tectonic and hydrothermal origin (OCI)}

The ophicarbonates of tectonic and hydrothermal origin (OCI) contain several generations of carbonate veins overprinting the serpentinized precursor. Calcium carbonate is the most widespread mineral, ubiquitous in these rocks at this stage. Samples can display variably extensive carbonation of the starting serpentinite during the hydrothermal activity. The amounts of vein-related calcite can range from few modal \% calcite (e.g., ZRL 15-3) to more than $80 \%$ (e.g., MNT 13-5) of the host rock. The host serpentinite has the texture of a jigsaw puzzle breccia with clasts ranging in size from the outcrop scale ( $\mathrm{m}$ in size) to handsample size (few $\mathrm{cm}$ )- and to $\mathrm{mm}$-scale. The ultramafic clasts also display varying extents of carbonation, from less than $20 \%$ (ISC 13-1) to $90 \%$ (ZRL 13-1) in volume.

The ultramafic clasts correspond to fully serpentinized peridotites, which do not 233 preserve olivine and which rarely preserve relict mantle pyroxene and spinel partially 
234 converted to magnetite. The clasts of the host serpentinite are heterogeneous in size and 1235 polygonal in shape, with sub-angular to angular edges. Each clasts preserves a record of the

2

original undeformed and deformed structure of the serpentinized mantle peridotite host. The monotonous chrysotile + magnetite assemblage of the pure serpentinite clasts is locally accompanied by formation of chlorite, talc and tremolite. Near the calcite hydrothermal veins, the serpentinite clasts unaffected by carbonation and preserving mantle pyroxene relics show evidence of infiltration in the form of small- to medium- sized calcite veinlets.

The serpentinite clasts are affected by varying degrees of carbonation: from minor overgrowth by neoblastic fine-grained calcite to reddish clasts showing pervasive to full carbonation associated with oxidation. This carbonation represent a key feature of such hydrothermally-altered oceanic ophicarbonates: full carbonation of the ultramafic silicate clasts concurs with formation of variably abundant hematite after magnetite. Replacement by calcite of serpentine from the core of the mesh texture and along cleavage of the former pyroxene by calcite occurs in nearly all oceanic samples. Locally, along the cleavages of serpentinized pyroxenes, trails of small green andraditic garnet crystals are intergrown with serpentine and calcite (Fig. 2C). In samples where the carbonation has been quite extensive, the serpentinite clasts are entirely replaced by fine-scale calcite grains and a film of hematite grows along the border, giving them a ghost-like texture (Fig. 2A, B). Interestingly, the full carbonation of the ultramafic silicate clasts appears to be associated with the formation of abundant hematite (Fig. 2A, B), suggesting that the $\mathrm{Fe}^{2+}$ released by the carbonated silicates was converted to $\mathrm{Fe}^{3+}$ thus stabilizing hematite due to increased oxidizing conditions.

The last brittle deformation event recorded by these rocks is represented by the formation of calcite veins that crosscut all previous structures. Calcite is coarse-grained and shows euhedral habit and, typically, twinning. Talc is observed in drusy textures commonly in 258 the core of the veins, seemingly representing as the last precipitates. In some samples, calcite 259 is replaced by talc aggregates (Fig. 2D). 
2

\section{Sedimentary ophicarbonates (OCII)}

These rocks display a sedimentary breccia-like texture with clasts consisting of serpentinites or of reworked OCI. The sedimentary OCII clasts typically display angular edges and widely varying grain size from several millimeters to few hundreds of micrometers. The mineral assemblage of the clasts, as in the OCI, consists of serpentine, magnetite, chlorite, talc and minor tremolite. Based on the extent of carbonation and oxidation, two types of sedimentary breccias can be identified: (i) samples SG 15-4 and MNT 15-2, showing minor and abundant carbonation and oxidation, respectively, and (ii) sample SG 15-2, showing intermediate amounts of carbonation and oxidation.

The green colour of ophicarbonate SG 15-4 reflects the high modal abundance of hydrous silicate minerals still preserved in the rock. The textures of the serpentinite clasts preserve the mantle mineral domains; however, some clasts with complex texture likely derive from pre-existing serpentine veins. The matrix calcite range from micritic to sparry, the latter occurrence type showing twinning. The sedimentary structures are cut by calcite veins showing, from rim to core, a change from botryoidal to irregular blocky textures (Fig. 2E).

The ophicarbonate sample MNT 15-2 shows an intense degree of carbonation and oxidation, with a reddish color due a large amount of hematite (Fig. 2F). In sample SG 15-2, only a few $\%$ of the clasts still preserve the original serpentinite composition, while widespread ghost-like textures derive from full replacement of former silicate minerals by fine-grained calcite. Locally, the clasts are composed of single crystals of calcite, probably derived from reworking of the OCI and associated hydrothermal calcite veins. The matrix of sample MNT 15-2 consists mainly of medium- to fine-scale (to microcrystalline) grains of anehdral calcite with lobate and irregular intercrystalline boundaries. Along the contact between the clasts and the matrix, calcite grows as cement crusts typically forming gravitational beard-like patterns. 


\subsection{Subduction-related ophicarbonates}

Pumpellyite-actinolite-facies ophicarbonates

Samples PL 13-1 and PL 13-2 display two texturally different types of micro-domains indicating multiple stages of recrystallization of calcite grains. The first micro-domain consists of coarse- to medium-sized grains of calcite (1) showing development of a second generation of twin lamellae cutting at high angles the earlier-formed generation and affected by growth of twin-free calcite grains. The coarse calcite (1) is cut by shear zones that represent the second type of micro-domain observed in these samples. The shear zones consist of medium- to fine- grained, un-twinned calcite (2) irregular in shape and with complex grain boundaries. Along the shear zones, calcite (1) is partially recrystallized and becomes elongated and re-oriented coherently into the shear zone orientation (Fig. 3A). Both samples (PL 13-1 and PL 13-2) also contain 10-20 volume \% serpentinite clasts ranging in size from several centimetres to a few millimetres. In general, the largest clasts are broken into smaller pieces when embedded and displaced along the shear-zones as sigmoidal porphyroclasts. The serpentine clasts consist of magnetite and antigorite showing tabular and interlocking textures grown at the expense of mesh-like lizardite/chrysotile. In shear zones, thin dark films of antigorite are interlayered with the calcite (2), giving to the rock an S-C like texture. The serpentinite clasts in these samples thus derive from an early stage of oceanic serpentinization and carbonation.

A key feature pertaining to these samples is the replacement of antigorite within the clasts by neoblastic calcite. Calcite overgrowths occur along the contacts between antigorite and calcite within the shear zones and inside the various serpentine clasts (Fig. 3B). These textures indicate that replacement of serpentine by calcite was due to syn-deformation infiltration by carbonic fluids. 


\section{Blueschist-facies ophicarbonates}

Samples CU3 and CU 13-1 represent ophicarbonates re-equilibrated at blueschist-facies $P-T$ conditions. CU3 consists of coarse serpentinite clasts in a coarse-grained calcite matrix. In the clasts, antigorite overgrows earlier serpentine minerals and, in the majority of the clasts, the original serpentinite texture is cross-cut and overgrown by networks of calcite-bearing veins. The coarse-grained matrix-forming calcite is anhedral and shows corroded grain boundaries, undulose extinction, and abrupt change in the twin growth, features that together represent deformation during crystallization. The calcite grains formed along the contacts with the serpentinite clasts and within the fracture network (Fig. 3C) display elongate textures suggesting syn-deformation crystallization.

Sample CU 13-1 shows the development of carbonate-rich shear zones alternating with domains with abundant serpentinite clasts. The shear zone textures are quite similar to those in samples PL 13-1 and PL 13-2 and are characterized by re-orientation of calcite and serpentinite clasts along the shear foliation and by crystallization of neoblastic calcite emanating from the grain boundaries of former calcite (Fig. 3D). Deformation within the shear zones leads to fracturing of the serpentinite clasts, grain size reduction, and uniform orientation of the antigorite flakes. Within the shear zones, the matrix calcite is very finegrained (maximum $100 \mu \mathrm{m}$ ) and shows heterogranular and hypidiotopic fabric typical of dynamic recrystallization and imparting a marble-like texture. The lack of twin lamellae in this type of calcite suggests an increase in the $T$ conditions with respect to that experienced by

332 the coarse-grained calcite crystals.

334 Eclogite-facies ophicarbonates

Samples from the La Pesca locality (LP13 EOC1 and LP13 EOC3) display an antigorite

336 + calcite + magnetite ( \pm hydro-garnet in sample LP13 EOC1) mineral assemblage. As in the 337 oceanic samples, garnet forms along the cleavages of the serpentinized pyroxene and, locally, 
around magnetite pods displaced along the main foliation (Fig. 3E). As often occurs in

1339

2

serpentinite, the magnetite pods may derive from oceanic alteration and recrystallization of Cr-rich mantle spinel. The main difference between the two La Pesca samples is the strong deformation affecting LP13 EOC3, a texture similar to that of samples CU 13-1 and PL 131/2. Despite the textural similarity to CU 13-1 and PL 13-1/2, deformed calcite in sample LP13 EOC3 is much finer-grained and contains more equigranular fabrics and hypidiotopic to idiotopic crystals. Sample LP13 EOC1 largely consists of calcite veins cutting the entire rock structure and suggesting late (subduction-related?) infiltration of C-bearing fluids along fractures.

The S. Anna ophicarbonates are the only samples showing dolomite and magnesite associated with antigorite, magnetite, minor chlorite, and diopside. In these rocks, coarse porphyroclastic magnesite occurs within the foliation produced at high- $P$ conditions, probably as the result of tectonic dismemberment of former veins (sample SA 15-8). An interesting feature of this magnesite is the presence of primary and pseudo-secondary fluid inclusions (Figs. 3G, 3H) showing tabular shapes, variable size (from 20 to few $\mu \mathrm{m}$ ) and infilling by liquid + gas. Occasionally, small aggregates of Ti-clinohumite are present and associated with the magnesite grains. Magnesite is partially replaced by dolomite and calcite along contacts with antigorite and, concurrent with this replacement, acicular tremolite was formed after antigorite.

Sample SA 15-1 shows micro-scale shear zones similar to those found in the other subduction-related samples: in such sheared domains, dolomite is overgrown by calcite, antigorite and minor chlorite likely related to retrograde deformation. Though high- $P$ conditions were reached in the S. Anna area, as described in literature, no evidence of metamorphic olivine has been found in the samples investigated here. However, we interpret the dolomite + antigorite + diopside assemblage $($ Fig. 3F) as representing high- $P$ conditions 
363

comparable with those of the ophicarbonates from the Zermatt-Saas Unit (Chatillon area, W. Alps), the latter peak-metamorphosed at $1.4 \mathrm{GPa}$ and $450-550{ }^{\circ} \mathrm{C}$ (Driesner, 1993).

\section{Methods}

\subsection{Bulk rocks}

Whole rock major element analyses were performed at ActLabs Ltd. using a fusion technique employing a Li-metaborate/tetraborate fusion digested in a weak nitric acid and measured by ICP-OES. Accuracy and precision are estimated as better than $1 \%$. Loss on ignition (LOI) was determined by weight difference following ignition of samples in a furnace. The amount of $\mathrm{CO}_{2}$ was determined by calcimetry at the IGG-CNR (Pisa, Italy) by reacting small aliquot of sample (about $0.3 \mathrm{~g}$ ) with $\mathrm{HCl}$, and measuring the release of $\mathrm{CO}_{2}$ from carbonates through the volume of water shifted in a graduated cylinder. The concentration is then calculated using a calibration line. The $\mathrm{CO}_{2}$ measured from sample containing the less-reactive magnesite in the assemblage (i.e., SA 15-8) may be underestimated. The amount of $\mathrm{H}_{2} \mathrm{O}$ was estimated by the simple difference between LOI and $\mathrm{CO}_{2}$ contents for each sample.

Trace element concentrations (except for B) were accomplished using an Agilent 7700x quadrupole ICP-MS at Géosciences Montpellier (AETE-ISO facility, Montpellier, France) following the procedure described in Godard et al. (2000) and Ionov et al. (1992). Boron concentrations for all samples were determined by isotope dilution using the NIST SRM 982 spike in a single collector VG Isomass 54E positive thermal ionization mass spectrometer (PTIMS) running in dynamic mode at the IGG-CNR (Pisa, Italy).

\subsection{Mineral compositions}

Major element mineral compositions were measured at the Department of Earth 388 Sciences, University of Milano (Italy), using the electron microprobe JEOL Superprobe 8200. 
The analyses were conducted with a WDS system at $15.0 \mathrm{kV}, 5 \mathrm{nA}$ for the electron beam and

$1 \mu \mathrm{m}$ beam size. We used natural silicate standards (the numbers refer to the international standards): $\mathrm{Mg}$ on olivine $153, \mathrm{Fe}$ on fayalite $143, \mathrm{Na}$ on omphacite 154 , Ti on ilmenite, $\mathrm{Mn}$ on rodonite, $\mathrm{K}$ on k-feldspar 113, $\mathrm{Al}$ and $\mathrm{Ca}$ on anorthite $137, \mathrm{Cr}$ on metallic/pure $\mathrm{Cr}$ and $\mathrm{Si}$ on wollastonite.

Mineral trace element concentrations were determined at the University of Bern by laser ablation, using a Geolas Pro 2006193 nm ArF excimer laser coupled to an Elan DRC-e ICPMS instrument (LA-ICP-MS). Analytical strategies, data reduction and instrument optimization procedures closely follow those reported by Spandler et al. (2011) and Pettke et al. (2012). Beam sizes were as large as possible (up to $160 \mu \mathrm{m}$ diameter) to lower the detection limits, calculated using the stringent formulation in Pettke et al. (2012). External standardization was against the GSD-1D basalt glass, employing the values cited in Peters and Pettke (2017) and the GeoRem data base (Jochum et al., 2005). Data reduction employed SILLS (Guillong et al., 2008), and the sum of all measured element oxides (total oxides, i.e., 100 wt.\% minus LOI; e.g., Halter et al., 2002) was used as the internal standard for quantification. Due to the lack of data for $\mathrm{Fe}^{3+} / \mathrm{Fe}^{2+}$, total $\mathrm{Fe}$ was calculated as $\mathrm{FeO}$. Ablation rates were turned to c. $0.08 \mu \mathrm{m}$ per pulse via attenuation of the laser output beam; the laser repetition rate was $10 \mathrm{~Hz}$. Measurement accuracy and precision were monitored by analysing SRM612 glass from NIST as an unknown, and the data mostly agree to within 5\% of the reference values (Supplementary Table A3).

\subsection{Isotopic analyses}

The samples were analyzed for $\delta^{13} \mathrm{C}$ and $\delta^{18} \mathrm{O}$ at the Department of Earth and Environmental Sciences, Lehigh University (USA), using a Finnigan MAT 252 gas massspectrometer coupled with a GasBench II system, applying the methods described by Cook414 Kollars et al. (2014) and Collins et al. (2015). We analyzed bulk rocks as well as more pure 
carbonates from different textural settings sampled by micro-drilling, using tungsten carbide bits with diameter of 1 and $2 \mathrm{~mm}$. Calcite, dolomite or magnesite was reacted at $72{ }^{\circ} \mathrm{C}$ for 30 min, 3 or 6 hours, respectively, with $0.2 \mathrm{~mL} 100 \%$ phosphoric acid $\left(\mathrm{H}_{3} \mathrm{PO}_{4}\right)$ in order to release $\mathrm{CO}_{2}$, according to the methods of McCrea (1950), Paul and Skrzypek (2007), and Sharma et al. (2002). All data are presented in standard delta( $\delta)$-notation, reported relative to VPDB and VSMOW for $\delta^{13} \mathrm{C}$ and $\delta^{18} \mathrm{O}$, respectively. Regular analyses of an in-house standard and the international standard NBS-19 allowed monitoring and correction of the data, resulting in a standard deviation $(1 \sigma)$ of $\sim 0.2 \%$ for both $\delta^{13} \mathrm{C}$ and $\delta^{18} \mathrm{O}$.

Strontium isotope analyses were performed using a Finnigan MAT 262 multicollector mass-spectrometer (at the IGG-CNR, Pisa, Italy), operated in dynamic mode, after ionexchange purification through $\mathrm{Sr}$-spec resin. Measured ${ }^{87} \mathrm{Sr} /{ }^{86} \mathrm{Sr}$ ratios were normalized to ${ }^{86} \mathrm{Sr} /{ }^{88} \mathrm{Sr}=0.1194$. Replicate analyses of NIST SRM $987\left(\mathrm{SrCO}_{3}\right)$ standard gave an average value of $0.710207 \pm 13(2 \mathrm{SD}, \mathrm{n}=5)$. Published values are adjusted to ${ }^{87} \mathrm{Sr} /{ }^{86} \mathrm{Sr}=0.710250$. Strontium blanks were about $0.3 \mathrm{ng}$, which are negligible given the $\mathrm{Sr}$ concentrations in the samples analyzed in this study.

\section{Results}

\subsection{Bulk rock major and trace element concentrations}

The major element whole-rock concentrations of the samples are reported in Table $\mathbf{1 .}$

434 The compositions of ophicarbonates are linked to the proportion of ultramafic and carbonate 435 component present: here, the composition of a pure serpentinite and an oceanic limestone (MNT 15-1 and ZRL 15-7, respectively) were considered as the end-members for all of the ophicarbonate rocks that were investigated. The major element compositions of OCI and OCII ophicarbonates plot along a linear array in a $\mathrm{CaO}, \mathrm{MgO}$ and $\mathrm{SiO}_{2}$ diagram, as do the subduction-related ophicarbonates. Similar variations in $\mathrm{CO}_{2}$ and $\mathrm{H}_{2} \mathrm{O}$ with respect to $\mathrm{MgO}$ and $\mathrm{CaO}$ are displayed for all ophicarbonates, with rocks showing more evidence of 
recrystallization during subduction processes (e.g. PL 13-2, CU 13-1 and LP13 EOC3)

1442

2

3

4

5

6444

7

8445

9

10

plotting near the $\mathrm{CO}_{2}$-rich end-member (Fig. 4). Sample SA 15-8, which contains magnesite, has a slightly higher $\mathrm{MgO}$ concentration and a lower $\mathrm{CaO}$ concentrations than the other subduction-related ophicarbonates (Fig. 4).

Trace element whole-rock compositions of the samples are reported in Table $\mathbf{1}$ and in Fig. 5. The pure serpentinite sample MNT 15-1 shows low REE concentrations with respect to primitive mantle values (PM, McDonough and Sun, 1995) and a negligible negative Eu anomaly. The strong light (L)REE depletion relative to concentrations of medium (M)REE and heavy $(\mathrm{H}) \mathrm{REE}\left(\mathrm{La}_{N} / \mathrm{Nd}_{\mathrm{N}}=0.15 ; \mathrm{Sm}_{N} / \mathrm{Ho}_{\mathrm{N}}=0.36 ; \mathrm{Er}_{N} / \mathrm{Lu}_{\mathrm{N}}=0.81\right)$ suggests a depleted harzburgite protolith. The limestone sample ZRL 15-7 is enriched in LREE to MREE whereas the HREE are almost flat $\left(\mathrm{La}_{N} / \mathrm{Nd}_{N}=2.63 ; \mathrm{Sm}_{N} / \mathrm{Ho}_{\mathrm{N}}=2.07 ; \mathrm{Er}_{N} / \mathrm{Lu}_{\mathrm{N}}=1.19\right)$. This sample shows a negative Eu anomaly $\left(\left(\mathrm{Eu} / \mathrm{Eu}^{*}\right)_{\mathrm{N}}=0.85\right)$.

OCI rocks have complex REE patterns, showing varying degrees of enrichment in LREE $\left(\mathrm{La}_{N} / \mathrm{Nd}_{\mathrm{N}}=1.76-3.80\right)$ and relative depletion in MREE and HREE but with similar $\mathrm{Sm}_{N} / \mathrm{Ho}_{\mathrm{N}}$ and $\mathrm{Er}_{\mathrm{N}} / \mathrm{Lu}_{\mathrm{N}}$ ratios (0.35 and 0.82 , respectively) compared to pure serpentinite sample. Only sample ISC 13-1 shows a higher concentration of MREE $\left(\mathrm{Sm}_{\mathrm{N}} / \mathrm{Ho}_{\mathrm{N}}=0.89\right)$. Of the OCI samples, ZRL 13-1 is the only rock with a positive Eu anomaly. The REE patterns of the sedimentary ophicarbonates (OCII) are comparable to those of the OCI rocks, with the exception of sample SG 15-2 that is far more enriched in all REE $\left(\mathrm{La}_{N} / \mathrm{Nd}_{\mathrm{N}}=1.78 ; \mathrm{Sm}_{N} / \mathrm{Ho}_{\mathrm{N}}\right.$ $\left.=0.89 ; \mathrm{Er}_{N} / \mathrm{Lu}_{\mathrm{N}}=0.93\right)$, although the concentrations are all below those of primitive mantle to which they are normalized. All ophicarbonates have negative $\mathrm{Ce}$ anomalies, with $\left(\mathrm{Ce} / \mathrm{Ce}^{*}\right)_{\mathrm{N}}$ ranging from 0.12 to 0.80 .

Pumpellyite-actinolite-facies ophicarbonates (PL 13-1 and 2) are homogeneous in their abundances of REE with concentrations far lower than those of the primitive mantle. Overall, their REE concentrations differ greatly from those of the oceanic ophicarbonates. More specifically, they show enrichment in $\operatorname{LREE}\left(\mathrm{La}_{\mathrm{N}} / \mathrm{Nd}_{\mathrm{N}}=2.77\right)$ without negative Ce anomalies, 
relatively flat MREE and HREE patterns $\left(\mathrm{Sm}_{N} / \mathrm{Ho}_{\mathrm{N}}=1.09 ; \mathrm{Er}_{N} / \mathrm{Lu}_{\mathrm{N}}=0.89\right)$, and positive $\mathrm{Eu}$

anomalies $\left(\left(\mathrm{Eu} / \mathrm{Eu}^{*}\right)_{\mathrm{N}}=1.81\right)$.

Blueschist-facies ophicarbonates CU3 and CU 13-1 have similar REE patterns, differing only in their HREE concentrations, the latter lower in sample CU 13-1 $\left(\operatorname{Er}_{N} / \operatorname{Lu}_{N}=\right.$ 2.50 against 1.05). They display a slight enrichment in $\operatorname{LREE}\left(\mathrm{La}_{\mathrm{N}} / \mathrm{Nd}_{\mathrm{N}}=0.74-0.48\right)$, slight depletion in MREE $\left(\mathrm{Sm}_{\mathrm{N}} / \mathrm{Ho}_{\mathrm{N}}=1.25-1.35\right)$ and positive Eu anomalies $\left(\left(\mathrm{Eu} / \mathrm{Eu}^{*}\right)_{\mathrm{N}}=1.46-\right.$ 1.51). For these samples, all PM-normalized REE concentrations fall between 0.1 and 1 .

The eclogite-facies ophicarbonate LP13 EOC1 shows LREE enrichment $\left(\mathrm{La}_{N} / \mathrm{Nd}_{\mathrm{N}}=\right.$ 2.24) with a strong negative Ce anomaly, and enrichment of MREE relative to HREE $\left(\mathrm{Sm}_{\mathrm{N}} / \mathrm{Lu}_{\mathrm{N}}=0.54\right)$. Europium shows a slight negative anomaly. Sample LP13 EOC3 shows a similar REE pattern $\left(\mathrm{La}_{N} / \mathrm{Nd}_{N}=1.18\right.$ and $\left.\mathrm{Sm}_{N} / \mathrm{Lu}_{\mathrm{N}}=0.62\right)$, but about 1 order of magnitude lower on the normalized plot. The negative $\mathrm{Ce}$ anomaly is less pronounced and Eu shows a slight positive anomaly. The eclogite-facies sample SA 15-1, from the S. Anna locality in the Voltri Massif, displays a low $\mathrm{La}_{N} / \mathrm{Nd}_{\mathrm{N}}$ ratio (0.70) and shows MREE enrichment relative to HREE $\left(\mathrm{Sm}_{N} / \mathrm{Lu}_{\mathrm{N}}=3.64\right)$. The magnesite-bearing ophicarbonate (SA 15-8) shows enriched REE concentrations, relative to primitive mantle values, with LREE lower than MREE and $\operatorname{HREE}\left(\mathrm{La}_{N} / \mathrm{Lu}_{\mathrm{N}}=0.33\right)$ and almost flat $\operatorname{HREE}\left(\mathrm{Er}_{\mathrm{N}} / \mathrm{Lu}_{\mathrm{N}}=0.92\right)$. Both SA $15-1$ and SA 15-8 show negative Eu anomalies.

The primitive mantle-normalized (PM, McDonough and Sun, 1995) trace elements concentrations of the serpentinite end-member (Fig. 5C) are similar to those of seafloor serpentinites imparted by interaction with seawater-derived fluids. These similarities include enrichment in B in (up to 100 times $\mathrm{PM}$ ) and positive anomalies in $\mathrm{Li}, \mathrm{Pb}, \mathrm{As}, \mathrm{Sb}$ and $\mathrm{Sr}$, but always at concentrations lower than those of the primitive mantle. Cesium and $\mathrm{Rb}$ concentrations are below detection limits and $\mathrm{Ba}, \mathrm{U}$ and $\mathrm{Th}$ concentrations also are very low.

Carbonation processes lead to varying degrees of enrichment in LILE and fluid-mobile elements (FME; e.g., As, Sb, U, Sr and Li) in the oceanic ophicarbonates OCI and OCII (Fig. 
493

5C). Similarity in the extents of enrichment in LILE, B, U, Th, $\mathrm{Pb}$ and $\mathrm{Li}$ is common for the subduction-related ophicarbonates (Fig. 5D). The trace element compositions of the eclogitic samples are comparable to those of the other subduction-related ophicarbonates, with the main differences being their higher $\mathrm{Pb}, \mathrm{As}$ and $\mathrm{Sb}$ concentrations. Niobium and $\mathrm{Ta}$ concentrations in sample SA 15-8 are near primitive mantle values whereas the concentrations of these elements in all other samples are very low (between 0.002 and 0.1 normalized to PM values).

\subsection{Mineral chemistry and in situ trace element concentrations}

Major element compositions of representative analyses of minerals in each sample are reported in the Table $\mathbf{2}$ and $\mathbf{3}$ and in the Supplementary Table S1 and a detailed description of the chemistry of the rock-forming minerals is reported in the Supplementary Material 1. Briefly, the serpentine from oceanic and subduction-related ophicarbonates shows major element composition similar to that of serpentine in the pure serpentinite sample characterized by high $\mathrm{MgO}$ and $\mathrm{SiO}_{2}$ contents and varying amounts of $\mathrm{TiO}_{2}, \mathrm{Al}_{2} \mathrm{O}_{3}$ and $\mathrm{Cr}_{2} \mathrm{O}_{3}$ related to the mantle mineral that was replaced (i.e., olivine or pyroxenes). Calcium-carbonate $\left(\mathrm{CaCO}_{3}\right)$ is the dominant component of the carbonates in all oceanic and subduction-related ophicarbonates (> 96\%), except in eclogitic samples SA 15-8 and SA 15-1. The latter two samples contain magnesite $\left(\mathrm{MgCO}_{3}>82 \%\right.$ and $\left.\mathrm{FeCO}_{3}<18 \%\right)$ and dolomite (with a $\mathrm{Ca} / \mathrm{Mg}$ ratio near 1.2) as the most abundant carbonate minerals.

The in-situ trace element compositions of serpentines and carbonates from the studied samples are reported in Table 2, Table 3, and in Figure 6. When normalized to the primitive mantle values (Fig. 6A), the trace element patterns of serpentine minerals from oceanic 516 ophicarbonates show positive anomalies in $\mathrm{Cs}, \mathrm{U}, \mathrm{B}, \mathrm{As}, \mathrm{Sb}, \mathrm{Sr}$ and $\mathrm{Li}$, whereas other LILEs 517 and Th are depleted. Negative HFSE (High Field Strength Elements) anomalies also are present. Compared to the trace element concentrations of the pure oceanic serpentines (grey 
519 field in Fig. 6A), these serpentinites also are enriched in La with respect to Ce, compatible

1520 with the bulk-rock data for OCI and OCII. As expected, calcite in the OCI and OCII samples

2

(Fig. 6C) mostly shows enrichment in $\mathrm{Sr}$ with scattered enrichments in $\mathrm{Rb}, \mathrm{Ba}, \mathrm{B}, \mathrm{La}$ and $\mathrm{Li}$. Calcite from the less carbonated and less oxidized sample SG 15-4 has much higher U concentrations than the calcite in the other samples. As for the serpentine minerals, La in calcite is enriched relative to Ce (e.g., sample MNT 15-2, Fig. 6C).

Antigorite from subducted ophicarbonates (Fig. 6B) shows trace element concentrations comparable to those of the oceanic samples, except for variable $\mathrm{Sr}$ anomalies, with the concentrations in general lower than PM in the eclogitic samples and higher than PM in the all other rocks. Notably, As and Sb concentrations in the SA 15-1 and SA 15-8 samples fall at the upper limit of the oceanic field. In situ trace element analyses of the calcites in sample PL 13-2 revealed concentrations comparable to those of oceanic OCI (Fig. 6D). In contrast, the calcites in the blueschist-facies ophicarbonates are depleted in $\mathrm{Li}$ and enriched in $\mathrm{Pb}$ and MREE, relative to HREE, and show positive Eu anomalies (Fig. 6D) compared with calcite from the oceanic ophicarbonates. Carbonates in the eclogitic samples from La Pesca show trace element patterns comparable to those of oceanic ophicarbonates; however, they show enrichment in $\mathrm{W}$ and $\mathrm{Pb}$. Dolomite and calcite in sample SA 15-1 (S. Anna area) are characterized by strong enrichment in LREE, $\mathrm{Pb}, \mathrm{Sr}$ and MREE relative to HREE. Overall, the concentrations of nearly all trace elements in calcite in this sample are one order of magnitude higher than those in the dolomites. Magnesite in sample SA 15-8 show low 539 concentrations in all trace elements, with very low Sr contents, but with strong enrichment in HREE relative to MREE and LREE.

\subsection{Isotope geochemistry}

5.3.1 Carbon and oxygen isotope compositions of carbonates 
Whole-rock $\mathrm{C}$ and $\mathrm{O}$ isotope compositions of the carbonate in the ophicarbonate suite

analyzed here are listed in Table 4. The complete $\mathrm{C}$ and $\mathrm{O}$ isotope dataset for the microdrilled carbonates from each of the localities, itemized for texture and mineralogy, is provided in the Supplementary Table S2 and the Figure in Appendix A1.

The $\delta^{13} \mathrm{C}$ of the oceanic carbonates ranges from about 0.0 to $+3.0 \%$ (Fig. 7A), without any significant difference between calcite replacing silicates or calcite in the veins (see the Figure in Appendix A1). These results are compatible with previously published data for the Bracco ophicarbonates (Collins et al., 2015; Schwarzenbach et al., 2013). Carbonate in veins has $\delta^{18} \mathrm{O}$ values ranging from +18.2 to $+26.0 \%$, whereas values for carbonates within the serpentinite clasts and from the matrix in sedimentary rocks are lower, forming a cluster of +14.3 to $18.9 \%$ (Fig. 7A). The higher $\delta^{18} \mathrm{O}$ values correspond to calcite from late-stage veins (Fig. 2D).

Pumpellyite-facies ophicarbonates (Fig. 7B) show $\delta^{13} \mathrm{C}$ within the range of the Apennine ophicarbonates (from 0.0 to $+1.5 \%$ ) and the $\delta^{18} \mathrm{O}$ values form a tight cluster ranging from +14.4 to $+15.5 \%$. The blueschist-facies CU3 samples show similar $\delta^{13} \mathrm{C}(+0.1$ to $+0.9 \%$ ) and $\delta^{18} \mathrm{O}$ from +15.8 and $+17.9 \%$, but sample CU13-1 has negative $\delta^{13} \mathrm{C}$ value (2.7 to $-1.1 \%$ ) and $\delta^{18} \mathrm{O}$ ranging from +16.4 to $+18.1 \%$. The range shown by the latter sample is compatible with values obtained by Collins et al. (2015) for ophicarbonates and carbonated metabasaltic rocks from the same area (Fig. 7B). Eclogitic sample LP13 EOC3 has $\delta^{13} \mathrm{C}$ ranging from +0.7 to $+1.4 \%$ and $\delta^{18} \mathrm{O}$ from 14.1 to $15.7 \%$, whereas LP13 EOC1 shows 564 similar $\delta^{13} \mathrm{C}\left(+0.8\right.$ to $+1.6 \%$ ) but lower $\delta^{18} \mathrm{O}$ ranging from +10.8 and $+11.5 \%$ (Fig. $7 \mathbf{B}$ ). 565 Other Voltri Massif ophicarbonates from the S. Anna locality are similar in their $\delta^{13} \mathrm{C}(+0.4$ to $566+1.7 \%$ ) but slightly higher in their $\delta^{18} \mathrm{O}(+11.6$ to $+12.7 \%$, Fig. $7 \mathbf{B})$.

\subsubsection{Strontium isotope compositions}


Strontium isotope compositions were analyzed for whole-rocks (except for sample SA

15-1) and are listed in Table 4 and are plotted in Fig. 8, against $\delta^{18} \mathrm{O}$ and $\delta^{13} \mathrm{C}$. The ${ }^{87} \mathrm{Sr} /{ }^{86} \mathrm{Sr}$ data for the Northern Apennines samples are reported for an initial time of $160 \mathrm{Ma}$, whereas the measured ${ }^{87} \mathrm{Sr} /{ }^{86} \mathrm{Sr}$ ratio is reported for the subducted ophicarbonates. This choice is based on the fact that the extent of the $\mathrm{Sr}$ isotopic re-equilibration during subduction evolution is uncertain. However, as reported in Table 4, the differences between measured values and age-corrected $\mathrm{Sr}$ isotope compositions for the subducted-related samples (for the Voltri Massif of $33 \mathrm{Ma}$, Rubatto and Scambelluri, 2003) is very small (within the analytical error) due to the very low $\mathrm{Rb} / \mathrm{Sr}$ of the samples.

The ${ }^{87} \mathrm{Sr} /{ }^{86} \mathrm{Sr}$ of the pure serpentinite end-member is 0.706929 , which is compatible with values for serpentinite formed at the oceanic floor during interaction with seawater at Jurassic time (Jurassic seawater value $=0.7070$; Jones et al., 1994). The limestone is characterized by higher $\mathrm{Sr}$ isotope value of 0.707048 which is compatible with a reequilibration with Upper Crataceous seawater (Jones et al., 1994) as proposed by Barbieri et al. (1979). Ophicarbonates of tectonic and sedimentary oceanic origins show ${ }^{87} \mathrm{Sr} /{ }^{86} \mathrm{Sr}$ ratios similar to those of the pure serpentinite, ranging from 0.705746 to 0.706703 . This range confirms the Jurassic oceanic imprint of the ophicarbonates due to interaction between seawater-derived fluids in hydrothermal systems. The pumpellyite- and blueschist-facies ophicarbonates from Pietralavezzara and Ubaye show similar values ranging from 0.706383 to 0.706833 . The only exception is for sample CU1 13-1 that displays a slight enrichment in 589 radiogenic Sr up to a value of 0.707530 , well above the values for Jurassic and Cretaceous seawater. The ${ }^{87} \mathrm{Sr} /{ }^{86} \mathrm{Sr}$ of sample LP13 EOC3 (0.706791) is comparable to that of oceanic rocks, whereas the other eclogitic ophicarbonates have far more radiogenic compositions: sample LP13 EOC1 and SA $15-8$ have ${ }^{87} \mathrm{Sr} /{ }^{86} \mathrm{Sr}=0.708453$ and 0.709670 , respectively, and 593 calcite and dolomite separates from sample SA $15-1$ have ${ }^{87} \mathrm{Sr} /{ }^{86} \mathrm{Sr}=0.707969$ and 0.708130 , 594 respectively. 


\section{Discussion}

Carbon release to subduction fluids and the mobility of aqueous-carbonic fluids within slabs or along the slab-mantle interface are actively debated topics in considerations of the solid Earth deep C cycle (Ague and Nicolescu, 2014; Berner, 1998; Collins et al., 2015; Cook-Kollars et al., 2014; Dasgupta and Hirschmann, 2010; Epstein et al., 2019; Jaeckel et al., 2018; Kelemen and Manning, 2015; Piccoli et al., 2016; Poli et al., 2009; Poli, 2015; Scambelluri et al., 2016). In this debate, a few studies have considered the geochemical evolution of ophicarbonates by investigating either the $\mathrm{C}-\mathrm{O}$ isotope compositions of carbonates (Collins et al., 2015; Driesner, 1993; Lafay et al., 2017; Scambelluri et al., 2016; Weissert and Bernoulli, 1984), or the radiogenic isotope and trace element compositions of bulk-rocks and of rock-forming minerals (Miller and Cartwright, 2000; Yamaguchi et al., 2012). Lacking have been studies combining field and petrographic observation, and petrologic work, with trace element concentrations and $\mathrm{C}, \mathrm{O}$, and $\mathrm{Sr}$ isotope compositions of oceanic and of subduction-zone ophicarbonates aimed at elucidating the geochemical evolution of carbonated serpentinite along the subduction interface. Such studies can build on previous work employing trace elements and $\mathrm{Sr}$ isotopes to trace fluid-infiltration in subducting ultramafic rocks (Cannaò et al., 2016, 2015; Harvey et al., 2014). The approach presented in this paper employs such an integration and offers new insight regarding the 614 mechanism of $\mathrm{C}$ mobilization in convergent margins.

bastite textures referred to as replacement of former mantle olivine and pyroxenes, 619 respectively (from $t_{0}$ to $t_{2}$ in Fig. 9). During tectonic fragmentation of the serpentinized mantle, carbonation of the bedrock by circulating hydrothermal fluids and accumulation of

\subsection{Textural and petrologic features}

The oceanic ophicarbonates studied here retain serpentine \pm magnetite mesh and 
621 serpentine clasts in sedimentary-tectonic breccias strongly affected the upper part of the

1622 ultramafic sequence (Schwarzenbach et al., 2013; Treves et al., 1995). Calcite formation after the production of the mesh textures (Fig. 2A), and along the cleavage of pseudomorph pyroxene, indicates that the mantle protolith was serpentinized prior to carbonation ( $\mathrm{t} 3$ in Fig. 9). Calcite formation after serpentinization requires open-system $\mathrm{Ca}$ and $\mathrm{CO}_{2}$ input by the hydrothermal fluids and the release of $\mathrm{Si}, \mathrm{Mg}$ and water (as hydroxyl molecules $-\mathrm{OH}^{-}$) into the fluid. Thermodynamic modelling suggests that serpentine replacement by carbonates occurred at $100{ }^{\circ} \mathrm{C}$ and $50 \mathrm{MPa}$ at a high activity of $\mathrm{CO}_{2}$ (Klein and Garrido, 2011). This modelling was confirmed by experimental work showing that formation of calcite or magnesite after serpentinization of peridotite is related to the activity of $\mathrm{Mg}^{2+}$ in the fluid and to the presence of relict mantle minerals (Grozeva et al., 2017). Serpentine carbonation can deliver abundant $\mathrm{Mg}$ and $\mathrm{Si}$ into the hydrothermal system with a consequent increase of the $\mathrm{Mg} / \mathrm{Ca}$ and $\mathrm{Si} / \mathrm{Ca}$ of the solutions. In the OCI and OCII ophicarbonates, the absence of $\mathrm{Mg}$ carbonates like dolomite and magnesite, and the only minor $\mathrm{MgCO}_{3}$ component in the calcite, indicates that the hydrothermal fluids reached $\mathrm{Mg}^{2+}$ saturation only after full consumption of the aqueous $\mathrm{CO}_{2}$. In fact, the last carbonation event led to formation of late-stage calcite and talc-bearing veins (Fig. 2D). Talc crystallization in such late-stage veins reflects the chemical evolution of hydrothermal fluids through time towards $\mathrm{Mg}$ - and $\mathrm{Si}$-rich, and $\mathrm{Ca}-$ and $\mathrm{CO}_{2}-$ depleted composition, and marks the end of the oceanic hydrothermal carbonation system ( $\mathrm{t} 4$ in Fig. 9). Figure 10 reports the results of thermodynamic calculations presented as an 641 activity-activity diagram $\left(\log \left(a \mathrm{SiO}_{2}\right)\right.$ vs. $\left.\log \left(a \mathrm{CO}_{2}\right)\right)$ simulating the oceanic carbonation of the 642 pure serpentinite sample MNT $15-1$ at low $T$ and $P$. The initial carbonation occurs at $643 \log \left(a \mathrm{CO}_{2}\right)$ values between -11.0 and -7.0 for a $\log \left(a \mathrm{SiO}_{2}\right)$ between -5.0 and -1.8 (red line in 644 Fig. 10). In this ranges of $\log \left(a \mathrm{SiO}_{2}\right)$ values, the complete carbonation of relicts of residual mantle minerals (e.g., olivine and pyroxenes) precedes the carbonation of serpentine, the latter occurring at $\log \left(a \mathrm{CO}_{2}\right)$ of -6.0 to -5.0 . This process is accompanied by release of $\mathrm{H}_{2} \mathrm{O}$ (blue 
647 line in Fig. 10). At high $\log \left(a \mathrm{SiO}_{2}\right)$ values, talc becomes stable (above -1.8, see the green line

in Fig. 10) over carbonates for a $\log \left(a \mathrm{CO}_{2}\right)$ greater than -6.5 .

The OCI and OCII ophicarbonates showing the highest modal proportions of rocksforming carbonate also display abundant hematite grains in the carbonated silicate domains and hematite rinds on carbonated clasts (Fig. 2A, B; t4 in Fig. 9). Overall, these features indicate highly oxidizing condition during carbonation, as also suggested by the formation of hydrous andradite-rich garnet in the bastite textures after former pyroxenes (Fig. 2C).

The above oceanic transformations created highly oxidized, hydrated, and carbonated serpentinite reservoirs hosting up to $40 \mathrm{wt} \% \mathrm{CO}_{2}$ (Fig. 4). Subduction of these rocks was accompanied by deformation of the oceanic textures (Stöckhert, 2002) with displacement and recrystallization of coarse oceanic calcite and serpentine along ductile shear zones (Fig. 3). At this stage, deformation might have occurred under chemically closed- or open-system conditions. The behaviour of these rocks during subduction can be revealed by textural analysis and study of geochemical markers. With the exception of samples SA 15-1 and SA 15-8, the majority of the subducted ophicarbonates for which data are presented here display antigorite + calcite as the main mineral assemblage. Their textures and mineral assemblage could reflect an internal redistribution/recrystallization of minerals and elements inherited from the oceanic stage. However, the pumpellyite- and the blueschist-facies samples are characterized by growth of secondary calcite after the serpentinization of the porphyroclasts displaced along the shear-zone foliation (Fig. 3B). The geometry of these clasts suggests syn667 tectonic carbonation of serpentine during early subduction stages. Experimental studies 668 showed that the solubility of calcite in $\mathrm{H}_{2} \mathrm{O}$-rich fluid increases with increasing $P-T$ conditions of the system (Caciagli and Manning, 2003), suggesting that the carbonation of the serpentinite clasts may have resulted from in-situ carbonate dissolution followed by in-situ 671 carbonate precipitation. Assuming a closed system condition, the $\mathrm{H}_{2} \mathrm{O}$ required to trigger 672 calcite dissolution may have been derived from the serpentinite clast itself as few wt.\% of 
$\mathrm{H}_{2} \mathrm{O}$ is released during the serpentine phase transition at increasing $P-T$ conditions (Schwartz

et al., 2013).

Additional textural evidence for $\mathrm{C}$ mobility during subduction is provided by the occurrence of carbonate veins crosscutting the eclogite-facies ophicarbonates in the Voltri Massif (LP EOC13-1). Another indication of open system behaviour and infiltration of Cbearing fluids precipitating eclogite-facies magnesite veins is provided by the abundant fluid inclusions hosted by porphyroclastic magnesite of sample SA 15-8. As shown in Fig. 11D, and as discussed below, these inclusions shows significant enrichment in FME relative to the concentrations in their magnesite hosts. This might be further evidence for infiltration of Cbearing fluids external to the ophicarbonate host.

Taken together, the textures and other observations presented above, for distinct domains in the ophicarbonates we investigated, provide a record of $\mathrm{C}$ mobilization over a wide range of $P-T$ conditions, beginning on the seafloor and during very early stages of subduction.

\subsection{Bulk and in-situ trace element features}

It has been demonstrated that the serpentinization of the oceanic mantle rocks does not strongly modify the REE composition of the peridotite protoliths (Deschamps et al., 2013 and reference therein). The REE composition of the reference serpentinite MNT 15-1 thus reasonably reflects its mantle protolith that is comparable to Internal Liguride (Liguria, Italy) 693 and Monte Maggiore (Corsica, France) peridotites (grey field in Fig. 5A; Rampone et al., 694 2008, 1996). The similarity in the trace element composition of rock-forming serpentine from 695 MNT 15-1 (showing positive B anomaly and depletion in LILE and FME; grey field in Fig. 696 6A) with other oceanic serpentinites (e.g., Kodolányi et al., 2012) confirms that the alteration 697 process occurred in a marine environment. In contrast, the carbonation of oceanic 698 serpentinites significantly affects REE concentrations (Fig. 5A; Allen and Seyfried, 2005). 
Accordingly, compared to serpentinite MNT 15-1, all of our oceanic ophicarbonates display

enrichments in La and variable depletion in Ce (Fig. 5A). The oxidation process that occurs during carbonation, revealed by conversion of magnetite to hematite, also affects the behaviour of $\mathrm{Ce}$ that, upon oxidized to $\mathrm{Ce}^{4+}$, becomes incompatible in the serpentine and carbonate. Cerium depletion is recorded by the bulk-rock and the mineral in-situ analyses of most oceanic ophicarbonates (Fig. 5A and 6A). The enrichment of $\mathrm{Ba}, \mathrm{B}, \mathrm{Cs}, \mathrm{U}, \mathrm{Pb}, \mathrm{As}, \mathrm{Sb}$, $\mathrm{Sr}, \mathrm{Li}$ in the oceanic ophicarbonates and their rock-forming serpentine and carbonate can be also linked to the carbonation and oxidation of these rocks (Andreani et al., 2014). Enrichment of FME in serpentine may be explained by the alkaline conditions of the hydrothermal environment increasing adsorption of these elements onto the serpentine mineral structure. According to the experimental work by Lafay et al., (2016) the As and Sb enrichments in serpentine (Fig. 6A) can be explained when considering that $\mathrm{As}^{5+}$ and $\mathrm{Sb}^{5+}$ are favourably sequestered by serpentine minerals, compared with $\mathrm{As}^{3+}$ and $\mathrm{Sb}^{3+}$, the latter which are mobilized in the fluid phase and/or precipitate as Sb-Ni-accessory phases. For the ophicarbonate calcite, the in-situ trace element concentrations are similar to those of serpentine, at least for As that is variably enriched. Uranium is mostly enriched in calcite in the less oxidized sample SG15-4, consistent with its high solubility at elevated oxygen fugacity (e.g., Bailey and Ragnarsdottir, 1994; Keppler and Wyllie, 1991). On the contrary, the Ce concentration in this sample is less depleted, perhaps indicating a key influence of oxygen fugacity in the Ce storage by ophicarbonate minerals.

The trace element patterns of the majority of the subducted ophicarbonates, and the minerals therein, do not display significant differences from the patterns in the oceanic samples (Figs. 5B, D and 6B, D). In particular, the coarse and recrystallized calcite in most deformed subduction-related samples do not show significant differences in their trace element budgets (Fig. 11A, B and C). This evidence suggests that C-mobilization in these samples occurred under closed-system conditions. The main differences in composition of the 
subduction-related ophicarbonates from the oceanic ones are demonstrated by data for the eclogitic samples SA15-1 and SA 15-8, which show the highest REE concentrations (note the enrichment in LREE relative to MREE and HREE in sample SA15-1, Fig. 5B) and higher Pb, As, Sb compared with concentrations in oceanic precursors (Fig. 5D). These bulk-rock anomalies are matched by enrichment in $\mathrm{Cs}, \mathrm{La}, \mathrm{Pb}, \mathrm{As}, \mathrm{Sb}$ of the rock-forming dolomite and calcite (Figs. 6B and D). Enrichment in these elements in ultramafic rocks have been attributed to exchange with sediment-derived fluids during subduction (Cannaò et al., 2016, 2015; Deschamps et al., 2011; Lafay et al., 2013). Therefore, the bulk-rock and in-situ trace element data suggest that both closed and open system conditions were experienced by ophicarbonates during the subduction, over their protracted metamorphic histories. In sample SA 15-8, the vein magnesite traps primary and pseudo-secondary inclusions (Fig. 3G, H) of the fluid that assisted magnesite growth. As expected, the LA-ICP-MS analyses of inclusionfree and of inclusion-bearing magnesite (Fig. 11D) shows that the latter displays much higher $\mathrm{Cs}, \mathrm{Ba}, \mathrm{B}, \mathrm{As}, \mathrm{Sb}, \mathrm{Rb}, \mathrm{W}, \mathrm{Pb}$ concentrations. This indicates that the fluid carried crustallyderived trace elements, either sourced in subducted sedimentary sequences, or released by dehydration of previously metasomatized altered oceanic crust or associated serpentinites (e.g., Cannaò and Malaspina, 2018 and reference therein).

\subsection{Tracing C mobility with $3 D$ isotopes}

The oceanic ophicarbonates studied here, like other oceanic ophicarbonates from the 745 Alps and Pyrenees (e.g., Clerc et al., 2014; Lafay et al., 2017), show wide ranges in O and C 746 isotope compositions (Fig. 7A), depending on the $T$ of serpentinization and on the amount of 747 reduced $\mathrm{C}$ contributing to the $\delta^{13} \mathrm{C}$ of the fluids involved (e.g., Alt et al., 2012b; Delacour et 748 al., 2008). In the oceanic ophicarbonates presented here, the $\mathrm{O}$ and $\mathrm{C}$ isotope compositions of 749 calcite are comparable to published values for the Northern Apennine area (Collins et al., 2015; Galli and Togliatti, 1965; Schwarzenbach et al., 2013). The calcite-seawater isotopic 
751

1752

2 3
4 753 5 6754 7 8 9 10 11

equilibrium indicates that ophicarbonate calcite grew after serpentine over a $T$ range of $130-$ $110{ }^{\circ} \mathrm{C}$ (assuming $\delta^{18} \mathrm{O}_{\text {seawater }}=0 \%$, O’Neil et al., 1969) in OCI and OCII. Lower $T$ of about $110-90{ }^{\circ} \mathrm{C}$ were obtained for calcite in veins cross-cutting all oceanic structures in OCI and OCII. These $T$ ranges are comparable to those calculated by Schwarzenbach et al. (2013) for ophicarbonates from the same area (between 150 and $50{ }^{\circ} \mathrm{C}$ ). All oceanic ophicarbonates presented here preserve a $\mathrm{C}$ isotope fingerprint consistent with acquisition of $\mathrm{C}$ during interaction with seawater-derived fluids. In OCII rocks, the matrix calcite in less oxidized samples (SG 15-4 and SG 15-2) shows slightly lower $\delta^{13} \mathrm{C}$ likely as the result of interaction with serpentinite clasts, showing isotopically negative values (Alt et al., 2012b; Lafay et al., 2017). The high degree of variability in the C-O isotope compositions of the oceanic protolith has to be taken into account when discussing the evolution of ophicarbonates during subduction evolution. The ${ }^{87} \mathrm{Sr} /{ }^{86} \mathrm{Sr}$ ratios of the oceanic ophicarbonates investigated here and of the pure serpentinite MNT 15-1 range between 0.7060 and 0.7070 (Fig. 8): such values approach the value of 0.7070 defined for Jurassic seawater (Jones et al., 1994), consistent with carbonation having involved Jurassic seawater re-equilibrated with a mafic/ultramafic reservoir.

Carbonate $\delta^{18} \mathrm{O}$ values for the pumpellyite- and of the blueschist-facies ophicarbonates overlap the lower- $\delta^{18} \mathrm{O}$ range for OCI and OCII. The $T$ range achieved for calcite crystallization in these rocks, based on $\delta^{18} \mathrm{O}$ values, is $130-90{ }^{\circ} \mathrm{C}$ (assuming $\delta^{18} \mathrm{O}_{\text {seawater }}=0 \%$, O’Neil et al., 1969). Such $T$ are in the range for alteration of the oceanic ophicarbonates, 771 indicating that these ophicarbonates retain the oceanic $\mathrm{O}$ isotope imprint of the protolith rocks. 772 Therefore, although subducted ophicarbonates can display either undeformed or deformed textures attributable to dynamic subduction-zone recrystallization, their $\delta^{18} \mathrm{O}$ does not require contribution by alteration after seawater-rock interaction. Whereas the $\mathrm{O}$ isotope compositions of these rocks are consistent with little or no subduction-related modification of seafloor compositions, the $\delta^{13} \mathrm{C}$ values (particularly that of sample $\mathrm{CU}$ 13-1) could reflect 
777

some modification by high- $P$ metamorphic fluids. The $\delta^{13} \mathrm{C}$ values of calcite in the pumpellyite-facies samples and the undeformed blueschist-facies sample CU3 show no significant deviation from the values expected for oceanic ophicarbonates (Fig. 7B), despite the sampling of two generations of early (coarse) and later (recrystallized) calcite in these subduction-zone metamorphosed samples (see Appendix Figure A1). Coupling this observation with the preservation of the oceanic $\delta^{18} \mathrm{O}$, with the ${ }^{87} \mathrm{Sr} /{ }^{86} \mathrm{Sr}$ signature (Fig. 8), and the in-situ trace element analyses (Fig. 11A) indicates inheritance of the oceanic compositions, at closed-system conditions, during subduction. In contrast, calcite in the deformed sample $\mathrm{CU}$ 13-1 has lower negative $\delta^{13} \mathrm{C}$ values (from -1 to $-2 \%$, Fig. 7B) that can be ascribed to either larger contribution from reduced/organic $\mathrm{C}$ during oceanic carbonation or the influence of reduced $\mathrm{C}$ during interaction with fluids sourced during subduction from the surrounding metasedimentary rocks (Collins et al., 2015; Cook-Kollars et al., 2014). The more radiogenic $\mathrm{Sr}$ isotope composition of CU 13-1 (Fig. 8) supports the second scenario (a metasedimentary source), despite the lack of evidence for significant trace element influx from sediments based on the in-situ analyses (Fig. 11B). Carbon additions from metasedimentary rocks into ultramafic ophicarbonates in the Queyras area has been documented by means of Fe and $\mathrm{Zn}$ isotope systematics by Debret et al. (2018), who showed that during subduction, these rocks underwent several stages of carbonate dissolution and precipitation involving sediment-derived fluids.

One eclogitic sample from the Voltri Massif (LP13 EOC3) affected by ductile 797 deformation and carbonate recrystallization displays $\delta^{13} \mathrm{C}$ and $\delta^{18} \mathrm{O}$ overlapping values for the 798 pumpellyite-facies rocks (Fig. 7B), suggesting a subduction evolution under closed-system 799 conditions. This interpretation is supported by a lack of enrichment in FME of the 800 recrystallized calcite (Fig. 11C) and by low radiogenic $\mathrm{Sr}$, with ${ }^{87} \mathrm{Sr} /{ }^{86} \mathrm{Sr}$ still compatible with 801 an oceanic fingerprint (Fig. 8). In contrast, the other eclogitic samples from Voltri Massif are 802 characterized by the lowest $\delta^{18} \mathrm{O}$ (down to $+10.5 \%$, Fig. 7B), matching with the compositions 
803 of the eclogite-facies ophicarbonates from the Zermatt-Saas Zone (Collins et al., 2015), 1804 whereas their $\delta^{13} \mathrm{C}$ values are similar to those of the other oceanic and subducted 828

ophicarbonates (Fig. 7B). Considering that in these samples, (i) magnesite veins formed during subduction (sample SA 15-8), (ii) dolomite crystallized together with antigorite and diopside under high- $P$ conditions (sample SA 15-1), and (iii) calcite veins crosscut the prograde antigorite (sample LP13 EOC1), and assuming that their original $\delta^{18} \mathrm{O}$ was the same as that of the oceanic ophicarbonates, the Voltri ophicarbonates are regarded as having reequilibrated with metamorphic fluids that lowered their seafloor-inherited $\delta^{18} \mathrm{O}$ (e.g., Miller and Cartwright, 2000). Decrease in the $\delta^{18} \mathrm{O}$ of these samples is coupled with increase in the FME budgets of carbonates (Fig. 6) and with the bulk-rock enrichment in radiogenic $\mathrm{Sr}$ (Fig. 8), indicating influx of externally-derived fluids.

Carbonic fluids sourced from metasedimentary rocks during prograde subduction should be characterized by high $\delta^{18} \mathrm{O}$ and low $\delta^{13} \mathrm{C}$, likely with radiogenic ${ }^{87} \mathrm{Sr} /{ }^{86} \mathrm{Sr}$ reflecting the elevated $\mathrm{Rb} / \mathrm{Sr}$ of the rocks (Cook-kollars et al., 2014; Yamaguchi et al., 2012). The $\delta^{18} \mathrm{O}$ values of calcite, dolomite and magnesite in the eclogitic ophicarbonates suggest that the fluids in equilibrium with these minerals should have $\delta^{18} \mathrm{O}$ values of +6.7 to $+10.5 \%$ (at peak $\mathrm{T}$ of $500{ }^{\circ} \mathrm{C}$ ), i.e., +3.8 to $+2.5 \%$ lower than the associated minerals (using the $\Delta^{18} \mathrm{O}_{\text {carbonate- }}$ water of Zheng, 1999). Such isotopic values are compatible with derivation of the fluids from altered oceanic crust and/or serpentinized mantle (Cartwright and Barnicoat, 1999) rather than sedimentary sources (see Jaeckel et al., 2018). However, the Sr isotope ratios of oceanic, mafic crustal reservoirs are generally less radiogenic than values for the ophicarbonates analyzed in this study. The conundrum is possibly solved by associating the isotopic imprints observed in the high- $P$ ophicarbonates with interaction with fluids released by devolatilization of hybridized ultramafic rocks bearing some sedimentary signatures. As a related example,

827 Cannaò et al. (2016) demonstrated that interaction of sediment-derived fluids with the Voltri serpentinites caused enrichments in FME and provided radiogenic $\mathrm{Sr}$ and $\mathrm{Pb}$. The subduction 
829 dehydration of such a hybrid serpentinite could have released hydrous fluids contributing the 1830 isotopic signatures to the subduction ophicarbonates analyzed in this study (high ${ }^{87} \mathrm{Sr} /{ }^{86} \mathrm{Sr}$,

low $\delta^{18} \mathrm{O}$, FME enrichment). Beginning with serpentinites with $+6 /+8 \%{ }^{18} \mathrm{O}$ (Cannaò et al., 2016; Früh-Green et al., 2001), the fluids released at 400 to $650{ }^{\circ} \mathrm{C}$, corresponding to the temperatures of olivine-in and antigorite-out reactions (Scambelluri et al., 1995), would have $\delta^{18} \mathrm{O}$ ranging from +7.2 to $+10.8 \%$. These values are in good agreement with those of the metamorphic fluids in equilibrium with carbonates from the subduction-zone ophicarbonates for which data are presented in this paper. The fluid generated by devolatilization of the serpentinite also would have low C/O ratio (Alt et al., 2012a), enabling retention of the C isotope compositions of the carbonates, even at fairly high fluid-rock ratios, but modifying the $\delta^{18} \mathrm{O}$ towards lower values. Alternatively, interaction of fluids derived by de-serpentinization with metasedimentary rocks along their flow paths in the subduction zone, could have led to the hybridized fluid compositions. Other recent studies of extensively veined mafic rocks and Schistes Lustrés adjacent to fault systems though to represent transient subduction interfaces has demonstrated shifts in $\delta^{18} \mathrm{O}$ to similar values and invoked infiltration by $\mathrm{H}_{2} \mathrm{O}$-rich fluids generated by dehydration of mafic and/or ultramafic rocks at greater depths (Angiboust et al., 2017; Epstein et al., 2019; Jaeckel et al., 2018).

\section{Conclusions}

In this study, we provide petrographic and geochemical constraints regarding fluid849 driven $\mathrm{C}$ mobility in ophicarbonates representing shallow levels of subduction zones and their equivalents subducted to depths experiencing eclogitic $P-T$ conditions. We characterize the sources of these fluids, identifying cases where compositions can be explained by closedsystem conditions and others where open-system fluid-rock interaction appears to have been 853 required. We demonstrate that decarbonation and dissolution/precipitation processes operating in ancient subduction zones are best traced using a combination of detailed field and 
petrographic observations, FME inventories and $\mathrm{C}-\mathrm{O}$ and $\mathrm{Sr}$ isotope systematics. We suggest that one challenge to our better understanding subduction zone $\mathrm{C}$ fluxes is the upscaling of observations from field and geochemical studies of high- $P$ metamorphic rocks to consideration of C cycling at Earth's modern consuming margins.

\section{Acknowledgements}

EC acknowledges funding by the Italian Society of Mineralogy and Petrology (SIMP award "Borsa di Studio per l'estero 2015") for supporting his visit to Lehigh University, and the CNR for providing a Short-Term Mobility grant to visit the Bern University for in-situ analyses. During the preparation of the manuscript EC was supported by the Italian MIUR PRIN project 2015C5LN35. The project has been supported by funds of the University of Genova and of the Italian MIUR to MS (MIUR PRIN projects 2012R33ECR_002 and 2017ZE49E7), of the USA-National Science Foundation to GEB (grant EAR-1119264) and of the IGG-CNR-P0000514 to SA. Constructive reviews by J. Alt and anonymous reviewer, and manuscript handling by Editor C. Chauvel, greatly improved the presentation of the manuscript and have been much appreciated.

\section{Figure Caption}

873 Figure 1

874 Simplified geological map of the Western Alps and location of the studied areas (modify after 875 Collins et al., 2015). (A) Geological map of Internal Liguride from the Ligurian N. Apennine

ophiolite (modified after Treves and Harper, 1994); (B) area of study from the Queyras/Ubaye zone (modified after Michard et al., 2004); (C) geological map of the Voltri Massif (modified after Cannaò et al., 2016 and reference therein). Locations of the collected samples for all three areas of study together with the respective sample' labels are indicated with the star symbol. 


\section{Figure 2}

Photomicrographs of the tectonic/hydrothermal (OCI) and sedimentary (OCII) ophicarbonates from the Northern Apennines: (A) parallel and (B) crossed polarized light microphotographs of completely carbonated serpentinite clast. Equant calcite grains overgrowing pseudomorphic serpentine minerals in the cell of mesh texture and a film of hematite grown along the border, giving them a ghost-like texture (OCI - MNT 13-5). (C) Former porphyroclast of serpentinized pyroxene (i.e., bastite; red dashed line) partially carbonated coupled with formation of oceanic garnet along the cleavage (OCI - ISC 13-1). (D) Talc aggregates overgrowing coarse grains of calcite in tardive veins. This represents the last process affecting the oceanic ophicarbonates (OCI - MNT 13-5). (E) Boytroidal versus irregular blocky calcite in vein (OCII - SG15-4). (F) Calcite in sedimentary matrix rich in hematite. Several serpentinite (Serp) clasts with irregular shape are visible (OCII - MNT 152).

\section{Figure 3}

Photomicrographs of the subducted ophicarbonates. (A) Old elongated and strained calcite grains, partially recrystallized along grain boundaries. Complete recrystallization of un899 twinned calcites along major shear zone is visible (PL 13-2). (B) Re-oriented serpentinite 900 clast along the shear zone partially carbonated (Carb clast). Relict of twinned calcites are 901 visible enclosed in recrystallized prograde calcite mylonites (PL 13-2). (C) Stretched 902 serpentinite clast (Serp) with microfractures and pressure shadows filled by syn-tectonic extensional calcite-fibers (Syn-tect. calcite). Syn-tectonic calcite is probably linked to the oceanic stage (CU3). (D) Dinamic recrystallization of old strained calcite porphyroclasts 905 producing fine untwinned calcite grains (CU 13-1). (E) Green garnet (Andradite) associated 906 with oxide (Cr-magnetite - Cr-mgt) and calcite along major deformation zone (LP13 EOC1). 
(F) Relict of the high pressure layer with dolomite + diopside + antigorite (SA 15-1). (G-H)

1908 Primary and pseudo-secondary fluid inclusions (FI) hosted in magnesite (Mgs) from sample

3909 SA $15-8$

6910

7

\section{Figure 4} members.

\section{Figure 5}

\section{Figure 6}

\section{Figure 7}

Bulk-rock major element data showing the relationship between $\mathrm{CaO}, \mathrm{MgO}$ and $\mathrm{SiO}_{2}$ of ophicarbonate rocks as well as variations in $\mathrm{CO}_{2}$ and $\mathrm{H}_{2} \mathrm{O}$ with respect to $\mathrm{MgO}$ and $\mathrm{CaO}$. Oceanic and subducted ophicarbonates fall in between pure serpentinite and limestone end-

Primitive mantle normalized (McDonough and Sun, 1995) Rare Earth Element (REE) and trace element patterns of ophicarbonates from oceanic $(\mathbf{A}, \mathbf{C})$ and subduction $(\mathbf{B}, \mathbf{D})$ stages. In (A) the grey field report the range of the peridotites from Internal Liguride (Rampone et al., 1996). In (B) and (D), the grey fields represent the REE and trace element pattern of the oceanic ophicarbonate illustrated in (A) and (C).

Primitive mantle normalized trace elements patterns of serpentine and carbonate from oceanic $(\mathbf{A}, \mathbf{C})$ and subduction (B, D) stages. In (B) and (D) grey fields represent the trace element variation of the serpentine and calcite from oceanic origin illustrated in (A) and (C). Primitive mantle normalization from McDonough and Sun (1995).

Oxygen $\left(\delta^{18} \mathrm{O}_{\text {VSMOW }}\right)$ and $\mathrm{C}\left(\delta^{13} \mathrm{C}_{\mathrm{VPDB}}\right)$ isotopic signatures of ophicarbonates from oceanic 932 (A) and subduction (B) stages. In (A) ophicarbonate fields from Bracco, the Pyrenean and 
933 Chenaillet (with different grey colours) are shown for comparison (from Collins et al., 2015;

1934 Clerc et al., 2014; Lafay et al., 2017). In (B) the Queyras and Zermatt-Saas fields are from

2

Collins et al., (2015) whereas Chatillon ophicarbonates field is from Driesner (1993). The complete $\delta^{18} \mathrm{O}$ vs. $\delta^{13} \mathrm{C}$ dataset is shown in the Appendix Figure A1 and in the

\section{Supplementary Table S2.}

\section{Figure 8}

${ }^{87} \mathrm{Sr} /{ }^{86} \mathrm{Sr} v s . \delta^{18} \mathrm{O}_{\text {VSMOW }}(\mathbf{A})$ and $\delta^{13} \mathrm{C}_{\text {VPDB }}$ (B) of ophicarbonates studied in this work. For comparison the values of the pure oceanic serpentinite and limestone form the Northern Apennines and of the Jurassic seawater are shown (dashed black lines).

\section{Figure 9}

Cartoon illustrating the sequence of hydration and carbonation/oxidation processes affecting mantle rocks at oceanic conditions. See text for discussion.

\section{Figure 10}

Activity-activity diagram for $\mathrm{Si}$ and $\mathrm{CO}_{2}\left(\log \left(a \mathrm{SiO}_{2}\right)\right.$ and $\log \left(a \mathrm{CO}_{2}\right)$, respectively) depicting phase equilibria in the $\mathrm{MgO}-\mathrm{CaO}-\mathrm{Al}_{2} \mathrm{O}_{3}-\mathrm{SiO}_{2}-\mathrm{H}_{2} \mathrm{O}-\mathrm{CO}_{2}$ system at $100{ }^{\circ} \mathrm{C}$ and 1500 bar (calculated using the Perple_X software, Connolly (2005) and the internal consistent thermodynamic database of Holland and Powell (1998) and the compensated Redlich-Kwong (CORK) equation of state of Holland and Powell (1991) for $\mathrm{H}_{2} \mathrm{O}$ and $\mathrm{CO}_{2}$ fluids). Key carbonate-in (in red), talc-in (in green) and release $\mathrm{H}_{2} \mathrm{O}$ (in blue) boundaries are emphasized. See text for discussion.

\section{Figure 11}


Comparison between in situ trace elements data for coarse and recrystallized calcite from

pumpelleyite- (A), blueschist- (B) and eclogite-facies (C) samples. Trace element compositions of fluid inclusion - magnesite mixed measurement compared with pure magnesite are reported in (D). Primitive mantle data from McDonough and Sun (1995).

\section{References}

Agard, P., Jolivet, L., Goffé, B., 2001. Tectonometamorphic evolution of the Schistes Lustres Complex; implications for the exhumation of HP and UHP rocks in the Western Alps. Bull. la Soc. Geol. Fr. https://doi.org/10.2113/172.5.617

Ague, J.J., Nicolescu, S., 2014. Carbon dioxide released from subduction zones by fluidmediated reactions. Nat. Geosci. 7, 355-360. https://doi.org/10.1038/ngeo2143

Allen, D.E., Seyfried, W.E., 2005. REE controls in ultramafic hosted MOR hydrothermal systems: an experimental study at elevated temperature and pressure. Geochim. Cosmochim. Acta 69, 675-683.

Alt, J.C., Crispini, L., Gaggero, L., Levine, D., Lavagnino, G., Shanks, P., Gulbransen, C., 2018. Normal faulting and evolution of fluid discharge in a Jurassic seafloor ultramafichosted hydrothermal system. Geology 46, 523-526. https://doi.org/10.1130/G40287.1

Alt, J.C., Garrido, C.J., Shanks, W.C.C., Turchyn, A., Padrón-Navarta, J.A., López SánchezVizcaíno, V., Gómez Pugnaire, M.T., Marchesi, C., Sánchez-Vizcaíno, V.L., Pugnaire, M.T.G., 2012a. Recycling of water, carbon, and sulfur during subduction of serpentinites: A stable isotope study of Cerro del Almirez, Spain. Earth Planet. Sci. Lett. 327, 50-60. https://doi.org/10.1016/j.eps1.2012.01.029

Alt, J.C., Schwarzenbach, E.M., Früh-Green, G.L., Shanks, W.C., Bernasconi, S.M., Garrido, C.J., Crispini, L., Gaggero, L., Padrón-Navarta, J.A., Marchesi, C., 2013. The role of serpentinites in cycling of carbon and sulfur: Seafloor serpentinization and subduction metamorphism. Lithos 178, 40-54. https://doi.org/10.1016/j.lithos.2012.12.006 
Alt, J.C., Shanks, W.C.C., Crispini, L., Gaggero, L., Schwarzenbach, E.M., Früh-Green, G.L., Bernasconi, S.M., 2012b. Uptake of carbon and sulfur during seafloor serpentinization and the effects of subduction metamorphism in Ligurian peridotites. Chem. Geol. 322323, 268-277. https://doi.org/10.1016/j.chemgeo.2012.07.009

Andreani, M., Escartin, J., Delacour, A., Ildefonse, B., Godard, M., Dyment, J., Fallick, A.E., Fouquet, Y., 2014. Tectonic structure, lithology, and hydrothermal signature of the rainbow massif (Mid-Atlantic Ridge 36 $6^{\circ} 14^{\prime} \mathrm{N}$ ). Geochemistry, Geophys. Geosystems. https://doi.org/10.1002/2014GC005269

Angiboust, S., Yamato, P., Hertgen, S., Hyppolito, T., Bebout, G.E., Morales, L., 2017. Fluid pathways and high-P metasomatism in a subducted continental slice (Mt. Emilius klippe, W. Alps). J. Metamorph. Geol. 35, 471-492. https://doi.org/10.1111/jmg.12241

Bailey, E.H., Ragnarsdottir, K. V, 1994. Uranium and Thorium Solubilities in Subduction Zone (Vol 124, Pg 119, 1994). Earth Planet. Sci. Lett. 128, 705-706.

Barbieri, M., Masi, U., Tolomeo, L., 1979. Stable isotope evidence for a marine origin of ophicalcites from the north-central Apennines (Italy). Mar. Geol. 30, 193-204. https://doi.org/10.1016/0025-3227(79)90015-X

Berner, R.A., 1998. The carbon cycle and CO2 over Phanerozoic time: The role of land plants. Philos. Trans. R. Soc. B Biol. Sci. 353, 75-82. https://doi.org/10.1098/rstb.1998.0192

Bonatti, E., 1976. Serpentinite protrusions in the oceanic crust. Earth Planet. Sci. Lett. 32, $107-113$.

Caciagli, N.C., Manning, C.E., 2003. The solubility of calcite in water at 6-16 kbar and 500$800{ }^{\circ}$ C. Contrib. to Mineral. Petrol. 146, 275-285. https://doi.org/10.1007/s00410-003$0501-y$

Cannaò, E., Agostini, S., Scambelluri, M., Tonarini, S., Godard, M., 2015. B, Sr and Pb isotope geochemistry of high-pressure Alpine metaperidotites monitors fluid-mediated element recycling during serpentinite dehydration in subduction mélange (Cima di 

https://doi.org/10.1016/j.gca.2015.04.024

Cannaò, E., Malaspina, N., 2018. From oceanic to continental subduction : Implications for the geochemical and redox evolution of the supra-subduction mantle 14 . https://doi.org/10.1130/GES01597.1/4457636/ges01597.pdf

Cannaò, E., Scambelluri, M., Agostini, S., Tonarini, S., Godard, M., 2016. Linking serpentinite geochemistry with tectonic evolution at the subduction plate-interface: The Voltri Massif case study (Ligurian Western Alps, Italy). Geochim. Cosmochim. Acta 190, 115-133. https://doi.org/10.1016/j.gca.2016.06.034

Carpena, J., Caby, R., 1984. Fission-track evidence for Late Triassic oceanic crust in the French Occidental Alps. Geology. https://doi.org/10.1130/00917613(1984)12<108:FEFLTO>2.0.CO;2

Cartwright, I., Barnicoat, A.C., 1999. Stable isotope geochemistry of Alpine ophiolites: A window to ocean-floor hydrothermal alteration and constraints on fluid-rock interaction during high-pressure metamorphism. Int. J. Earth Sci. 88, 219-235. https://doi.org/10.1007/s005310050261

Chiesa, S., Cortesogno, L., Forcella, F., Galli, M., Messiga, B., Pasquaré, G., Pedemonte, G.M., Piccardo, G.B., Rossi, P.M., 1975. Assetto strutturale ed interpretazione geodinamica del Gruppo di Voltri. Boll. Soc. Geol. Ital. 94, 555-581.

Cimmino, F., Messiga, B., Piccardo, G.B., Zeda, O., 1979. Titanian clinohumite-bearing assemblages within antigoritic serpentinitesof the Voltri Massif (Western Liguria): interferences on the geodynaminc evolution of piemontese ultramafic sections. Ofioliti 4, $97-120$.

Clerc, C., Boulvais, P., Lagabrielle, Y., Blanquat, M.D. Saint, 2014. Ophicalcites from the northern Pyrenean belt : a field, petrographic and stable isotope study 141-163. https://doi.org/10.1007/s00531-013-0927-z 
Collins, N.C., Bebout, G.E., Angiboust, S., Agard, P., Scambelluri, M., Crispini, L., John, T., 2015. Subduction zone metamorphic pathway for deep carbon cycling : II . Evidence from HP / UHP metabasaltic rocks and ophicarbonates. Chem. Geol. 412, 132-150. https://doi.org/10.1016/j.chemgeo.2015.06.012

Connolly, J.A.D., 2005. Computation of phase equilibria by linear programming : A tool for geodynamic modeling and its application to subduction zone decarbonation 236, 524541. https://doi.org/10.1016/j.eps1.2005.04.033

Cook-Kollars, J., Bebout, G.E., Collins, N.C., Angiboust, S., Agard, P., 2014. Subduction zone metamorphic pathway for deep carbon cycling: I. Evidence from HP/UHP metasedimentary rocks, Italian Alps. Chem. Geol. 386, 31-48. https://doi.org/10.1016/j.chemgeo.2014.07.013

Cortesogno, L., Galbiati, B., Principi, G., 1980. Le brecce serpentinitiche giurassiche della Liguria orientale. Arch. Sci. Genève 33, 185-200.

Cortesogno, L., Lucchetti, G., Massa, B., 1981. Rocce oficarbonate e marmi a silicati nel Massiccio di Voltri: origine e significato, chimismo dei minerali ed equilibri paragenetici. Rend. Soc. Ital. di Mineral. e Petrol. 37, 481-507.

Crispini, L., Capponi, G., 2001. Tectonic evolution of the Voltri Group and Sestri Voltaggio Zone (southern limit of the NW Alps): a review. Ofioliti 26, 161-164.

Dasgupta, R., Hirschmann, M.M., 2010. The deep carbon cycle and melting in Earth 's interior. Earth Planet. Sci. Lett. 298, 1-13. https://doi.org/10.1016/j.eps1.2010.06.039

Debret, B., Bouilhol, P., Pons, M.L., Williams, H., 2018. Carbonate transfer during the onset of slab devolatilization: New insights from fe and Zn stable isotopes. J. Petrol. 59, 11451166. https://doi.org/10.1093/petrology/egy057

Decandia, F.A., Lazzarotto, A., Liotta, D., Cernobori, L., Nicolich, R., 1998. The CROP3 traverse: insights on post-collisional evolution of Northern Apennines.

Delacour, A., Früh-Green, G.L., Frank, M., Gutjahr, M., Kelley, D.S., 2008. Sr-and Nd- 

isotope geochemistry of the Atlantis Massif (30 N, MAR): implications for fluid fluxes

Deschamps, F., Godard, M., Guillot, S., Hattori, K., 2013. Geochemistry of subduction zone serpentinites: A review. Lithos 178, 96-127. https://doi.org/10.1016/j.lithos.2013.05.019

Deschamps, F., Guillot, S., Godard, M., Andreani, M., Hattori, K., 2011. Serpentinites act as sponges for fluid-mobile elements in abyssal and subduction zone environments. Terra Nov. 23, 171-178.

Driesner, T., 1993. Aspects of Petrographic, Structural and Stable Isotope Geochemical Evolution of Ophicarbonate Breccias from Ocean-Floor to Subduction and Uplift - an Example from Chatillon, Middle Aosta Valley, Italian Alps. Schweizerische Mineral. Und Petrogr. Mitteilungen 73, 69-84.

Epstein, G., Angiboust, S., Bebout, G., 2019. Scales of Fluid-Rock Interaction and Carbon Mobility in the Deeply Underplated and HP -Metamorphosed Schistes Lustrés , Western Alps. LITHOS 105229. https://doi.org/10.1016/j.lithos.2019.105229

Federico, L., Capponi, G., Crispini, L., Scambelluri, M., 2004. Exhumation of alpine highpressure rocks: Insights from petrology of eclogite clasts in the Tertiary Piedmontese basin (Ligurian Alps, Italy). Lithos 74, 21-40.

https://doi.org/10.1016/j.lithos.2003.12.001

Federico, L., Crispini, L., Scambelluri, M., Capponi, G., 2007. Ophiolite melange zone records exhumation in a fossil subduction channel. Geology 35, 499-502. https://doi.org/10.1130/G23190A.1

Frezzotti, M.L., Selverstone, J., Sharp, Z.D., Compagnoni, R., 2011. Carbonate dissolution during subduction revealed by diamond-bearing rocks from the Alps. Nat. Geosci. 4, 703-706. https://doi.org/10.1038/ngeo1246

Früh-Green, G.L., Connolly, J.A.D., Plas, A., Kelley, D.S., Grobety, B., 2004. Serpentinization of Oceanic Peridotites : Implications for Geochemical Cycles and 

Biological Activity The Subseafloor Biosphere at Mid-Ocean Ridges. Geophys. Monogr. Ser. 144, 119-136.

Früh-Green, G.L., Scambelluri, M., Vallis, F., 2001. O-H isotope ratios of high pressure ultramafic rocks: Implications for fluid sources and mobility in the subducted hydrous mantle. Contrib. to Mineral. Petrol. 141, 145-159. https://doi.org/10.1007/s004100000228

Früh-Green, G.L., Weissert, H., Bernoulli, D., 1990. A multiple fluid history recorded in Alpine ophiolites. J. Geol. Soc. London. 147, 959-970. https://doi.org/10.1144/gsjgs.147.6.0959

Galli, M., 1957. Il Rosso di Levanto. Rend. Soc. Miner. Ital 13, 265-267.

Galli, M., Togliatti, V., 1965. Ricerche petrografiche sulla formazione ofiolitica dell'Appennino Ligure. Il Rosso di Levanto—nuovo contributo. Ann. Mus. Civ. St. Nat. Genova 75, 359-381.

Godard, M., Jousselin, D., Bodinier, J.-L., 2000. Relationships between geochemistry and structure beneath a palaeo-spreading centre: a study of the mantle section in the Oman ophiolite. Earth Planet. Sci. Lett. 180, 133-148.

Grozeva, N.G., Klein, F., Seewald, J.S., Sylva, S.P., 2017. Experimental study of carbonate formation in oceanic peridotite. Geochim. Cosmochim. Acta 199, 264-286. https://doi.org/10.1016/j.gca.2016.10.052

Guillong, M., Meier, D.L., Allan, M.M., Heinrich, C.A., Yardley, B.W.D., 2008. Appendix A6: SILLS: a MATLAB-based program for the reduction of laser ablation ICP-MS data of homogeneous materials and inlusions 328-333.

Halter, W.E., Pettke, T., Heinrich, C.A., Rothen-Rutishauser, B., 2002. Major to trace element analysis of melt inclusions by laser-ablation ICP-MS: Methods of quantification. Chem. Geol. 183, 63-86. https://doi.org/10.1016/S0009-2541(01)00372-2

113 Harvey, J., Garrido, C.J., Savov, I.P., Agostini, S., Padrón-Navarta, J.A., Marchesi, C., 
1114

11115

2 3116

5 6117 7 81118 10

Sánchez-Vizcaíno, V.L., Gómez-Pugnaire, M.T., 2014. 11 B-rich fluids in subduction zones: The role of antigorite dehydration in subducting slabs and boron isotope heterogeneity in the mantle. Chem. Geol. 376, 20-30.

Hermann, J., Müntener, O., Scambelluri, M., Mu, O., 2000. The importance of serpentinite mylonites for subduction and exhumation of oceanic crust. Tectonophysics $327,225-$ 238. https://doi.org/10.1016/S0040-1951(00)00171-2

Holland, T., Powell, R., 1991. A Compensated-Redlich-Kwong (CORK) equation for volumes and fugacities of $\mathrm{CO} 2$ and $\mathrm{H} 2 \mathrm{O}$ in the range 1 bar to $50 \mathrm{kbar}$ and $100-1600^{\circ} \mathrm{C}$. Contrib. to Mineral. Petrol. https://doi.org/10.1007/BF00306484

Holland, T.J.B., Powell, R., 1998. An internally consistent thermodynamic data set for phases of petrological interest. J. Metamorph. Geol. 16, 309-343. https://doi.org/10.1111/j.1525-1314.1998.00140.x

Hoogerduijn Strating, E.H., Rampone, E., Piccardo, G.B., Drury, M.R., Vissers, R.L.M., 1993. Subsolidus emplacement of mantle peridotites during incipient oceanic rifting and opening of the Mesozoic Tethys (Voltri Massif, NW Italy). J. Petrol. 34, 901-927.

Ionov, D.A., Savoyant, L., Dupuy, C., 1992. Application of the ICP-MS techmique to trace element analysis of peridotite and their minerals. Geostand. Newsl. 16, 311-315.

Jaeckel, K., Bebout, G.E., Angiboust, S., 2018. Deformation-enhanced fluid and mass transfer along Western and Central Alps paleo-subduction interfaces: Significance for carbon cycling models. Geosphere 14, 2355-2375. https://doi.org/10.1130/GES01587.1

Jochum, K.P., Nohl, U., Herwig, K., Lammel, E., Stoll, B., Hofmann, A.W., 2005. GeoReM: A New Geochemical Database for Reference Materials and Isotopic Standards. Geostand. Geoanalytical Res. 29, 333-338. https://doi.org/10.1111/j.1751-908x.2005.tb00904.x

Jones, C.E., Jenkyns, H.C., Coe, A.L., Stephen, H.P., 1994. Strontium isotopic variations in Jurassic and Cretaceous seawater. Geochim. Cosmochim. Acta 58, 3061-3074.

139 Kelemen, P.B., Manning, C.E., 2015. Reevaluating carbon fluxes in subduction zones, what 
goes down, mostly comes up. Proc. Natl. Acad. Sci. 112, E3997-E4006. https://doi.org/10.1073/pnas.1507889112

Kelley, D.S., Karson, J.A., Fru, G.L., Yoerger, D.R., Shank, T.M., Butterfield, D.A., Hayes, J.M., Schrenk, M.O., Olson, E.J., Proskurowski, G., Jakuba, M., Bradley, A., Larson, B., Ludwig, K., Glickson, D., Buckman, K., Bradley, A.S., Brazelton, W.J., Roe, K., Bernasconi, S.M., Elend, M.J., Lilley, M.D., Baross, J.A., Summons, R.E., Sylva, S.P., 2005. Kelley_05 307, 1-7.

Keppler, H., Wyllie, P.J., 1991. Partitioning of $\mathrm{Cu}$, Sn, Mo, W, U, and Th between melt and aqueous fluid in the systems haplogranite-H2O-HCl and haplogranite-H2O-HF. Contrib. to Mineral. Petrol. https://doi.org/10.1007/BF00306474

Kerrick, D.M., Connolly, J.A.D., 2001. Metamorphic devolatilization of subducted marine sediments and the transport of volatiles into the Earth' s mantle 36, 293-296.

Kerrick, D.M., Connolly, J.A.D., 1998. Subduction of ophicarbonates and recycling of CO2 and H2O. Geology 26, 375-378.

Klein, F., Garrido, C.J., 2011. Thermodynamic constraints on mineral carbonation of serpentinized peridotite. Lithos 126, 147-160. https://doi.org/10.1016/j.lithos.2011.07.020

Kodolányi, J., Pettke, T., Spandler, C., Kamber, B.S., Ling, K.G., Gme, K., 2012. Geochemistry of ocean floor and fore-arc serpentinites: Constraints on the ultramafic input to subduction zones. J. Petrol. 53, 235-270. https://doi.org/10.1093/petrology/egr058

Lafay, R., Baumgartner, L.P., Stephane, S., Suzanne, P., German, M.H., Torsten, V., 2017. Petrologic and stable isotopic studies of a fossil hydrothermal system in ultramafic environment (Chenaillet ophicalcites, Western Alps, France): Processes of carbonate cementation. Lithos 294-295, 319-338. https://doi.org/10.1016/j.lithos.2017.10.006

165 Lafay, R., Deschamps, F., Schwartz, S., Guillot, S., Godard, M., Debret, B., Nicollet, C., 2013. 
High-pressure serpentinites, a trap-and-release system controlled by metamorphic conditions: Example from the Piedmont zone of the western Alps. Chem. Geol. 343, 3854.

Lafay, R., Montes-Hernandez, G., Janots, E., Munoz, M., Auzende, A.L., Gehin, A., Chiriac, R., Proux, O., 2016. Experimental investigation of As, Sb and Cs behavior during olivine serpentinization in hydrothermal alkaline systems. Geochim. Cosmochim. Acta 179, 177-202. https://doi.org/10.1016/j.gca.2016.02.014

Lagabrielle, Y., 1987. Les ophiolites: marqueurs de l'histoire tectonique des domaines océaniques: le cas des Alpes franco-italiennes (Queyras, Piémont). Brest.

Lagabrielle, Y., Lemoine, M., Tricart, P., 1985. Paléotectonique océanique et déformations alpines dans le massif ophiolitique du Pelvas d'Abriès (Alpes Occidentales-QueyrasFrance). Bull. la Société Géologique Fr. 1, 473-480.

Lemoine, M., Tricart, P., Boillot, G., 1987. Ultramafic and gabbroic ocean floor of the Ligurian Tethys (Alps, Corsica, Apennines): in search of a genetic model. Geology 15, 622-625. https://doi.org/10.1130/0091-7613(1987)15<622:UAGOFO>2.0.CO;2

Leoni, L., Marroni, M., Sartori, F., Tamponi, M., 1996. Metamorphic grade in metapelites of the Internal Liguride Units (Northern Apennines, Italy). Eur. J. Mineral. 8, 70176. https://doi.org/10.1127/ejm/8/1/0035

Ludwig, K.A., Kelley, D.S., Butterfield, D.A., Nelson, B.K., Früh-Green, G.L., 2006. Formation and evolution of carbonate chimneys at the Lost City Hydrothermal Field. Geochim. Cosmochim. Acta 70, 3625-3645. https://doi.org/10.1016/j.gca.2006.04.016

Malaspina, N., Poli, S., Fumagalli, P., 2009. The oxidation state of metasomatized mantle wedge: Insights from C-O-H-bearing garnet peridotite. J. Petrol. 50, 1533-1552. https://doi.org/10.1093/petrology/egp040

Malatesta, C., Crispini, L., Federico, L., Capponi, G., Scambelluri, M., 2012. The exhumation of high pressure ophiolites (Voltri Massif, Western Alps): Insights from structural and 
petrologic data on metagabbro bodies. Tectonophysics 568-569, 102-123.

McCrea, J.M., 1950. On the isotopic chemistry of carbonates and a paleotemperature scale. J. Chem. Phys. https://doi.org/10.1063/1.1747785

McDonough, W.F., Sun, S.-S., 1995. The composition of the Earth. Chem. Geol. 120, 223253.

Messiga, B., Scambelluri, M., 1991. Retrograde P-T-T path for the Voltri-Massif eclogites (Ligurian Alps, Italy) - some tectonic implications. J. Metamorph. Geol. 9, 93-109.

Mével, C., 2003. Serpentinization of abyssal peridotites at mid-ocean ridges. Comptes Rendus Geosci. 335, 825-852.

Michard, A., Goffé, B., Avigad, D., 2004. The high-pressure metamorphic front of the south Western Alps (Ubaye-Maira transect, France, Italy). Schweizerische Mineral. und Petrogr. Mitteilungen 84, 215-235.

Miller, J.A., Cartwright, I., 2000. Distinguishing between seafloor alteration and fluid flow during subduction using stable isotope geochemistry: Examples from Tethyan ophiolites in the Western Alps. J. Metamorph. Geol. 18, 467-482. https://doi.org/10.1046/j.15251314.2000.00274.x

Molina, J.F., Poli, S., 2000. Carbonate stability and fluid composition in subducted oceanic crust: An experimental study on H2O-CO2-bearing basalts. Earth Planet. Sci. Lett. 176, 295-310. https://doi.org/10.1016/S0012-821X(00)00021-2

O’Hanley, D.S., 1996. Serpentinites. Oxford University Press on Demand.

O’Neil, J.R., Clayton, R.N., Mayeda, T.K., 1969. Oxygen isotope fractionation in divalent metal carbonates. J. Chem. Phys. 51, 5547-5558. https://doi.org/10.1063/1.1671982

Paul, D., Skrzypek, G., 2007. Assessment of carbonate-phosphoric acid analytical technique performed using GasBench II in continuous flow isotope ratio mass spectrometry. Int. J. Mass Spectrom. https://doi.org/10.1016/j.ijms.2006.11.006 
Peters, D., Pettke, T., 2017. Evaluation of Major to Ultra Trace Element Bulk Rock Chemical Analysis of Nanoparticulate Pressed Powder Pellets by LA-ICP-MS. Geostand. Geoanalytical Res. 41, 5-28. https://doi.org/10.1111/ggr.12125

Pettke, T., Oberli, F., Audétat, A., Guillong, M., Simon, A.C., Hanley, J.J., Klemm, L.M., 2012. Recent developments in element concentration and isotope ratio analysis of individual fluid inclusions by laser ablation single and multiple collector ICP-MS. Ore Geol. Rev. https://doi.org/10.1016/j.oregeorev.2011.11.001

Piccoli, F., Vitale, A., Beyssac, O., Martinez, I., Ague, J.J., Chaduteau, C., 2016. Carbonation by fluid - rock interactions at high-pressure conditions : Implications for carbon cycling in subduction zones. Earth Planet. Sci. Lett. 1, 1-14. https://doi.org/10.1016/j.eps1.2016.03.045

Poli, S., 2015. Carbon mobilized at shallow depths in subduction zones by carbonatitic liquids. Nat. Geosci. 8, 633-636. https://doi.org/10.1038/ngeo2464

Poli, S., Franzolin, E., Fumagalli, P., Crottini, A., 2009. The transport of carbon and hydrogen in subducted oceanic crust: An experimental study to 5 GPa. Earth Planet. Sci. Lett. 278, 350-360. https://doi.org/10.1016/j.epsl.2008.12.022

Rampone, E., Hofmann, A.W., Piccardo, G.B., Vannucci, R., Bottazzi, P., Ottolini, L., Hofmann, W., Piccardo, B., Vannucci, R., Bottazzi, P., Ottolini, L., 1996. Trace element and isotope geochemistry of depleted peridotites from an N-MORB type ophiolite (Internal Liguride, N. Italy). Contrib. to Mineral. Petrol. 123, 61-76. https://doi.org/10.1007/s004100050143

Rampone, E., Piccardo, G.B., Hofmann, A.W., 2008. Multi-stage melt-rock interaction in the Mt. Maggiore (Corsica, France) ophiolitic peridotites: Microstructural and geochemical evidence. Contrib. to Mineral. Petrol. 156, 453-475. https://doi.org/10.1007/s00410-0080296-y

243 Sapienza, G.T., Scambelluri, M., Braga, R., 2009. Dolomite-bearing orogenic garnet 
peridotites witness fluid-mediated carbon recycling in a mantle wedge (Ulten Zone,

Eastern Alps, Italy). Contrib. to Mineral. Petrol. 158, 401-420.

https://doi.org/10.1007/s00410-009-0389-2

Scambelluri, M., Bebout, G.E., Belmonte, D., Gilio, M., Campomenosi, N., Collins, N.,

Crispini, L., 2016. Carbonation of subduction-zone serpentinite ( high-pressure ophicarbonate; Ligurian Western Alps ) and implications for the deep carbon cycling. Earth Planet. Sci. Lett. 441, 155-166. https://doi.org/10.1016/j.eps1.2016.02.034

Scambelluri, M., Hoogerduijn Strating, E.H., Piccardo, G.B., Vissers, R.L.M., Rampone, E., 1991. Alpine olivine- and titanian clinohumite-bearing assemblages in the Erro-Tobbio peridotite (Voltri Massif, NW Italy). J. Metamorph. Geol. 9, 79-91.

Scambelluri, M., Muntener, O., Hermann, J., Piccardo, G.B., Trommsdorff, V., 1995. Subduction of water into the mantle: history of an Alpine peridotite. Geology. https://doi.org/10.1130/0091-7613(1995)023<0459:SOWITM>2.3.CO;2

Scambelluri, M., Tonarini, S., 2012. Boron isotope evidence for shallow fluid transfer across subduction zones by serpentinized mantle. Geology 40, 907-910.

Schwartz, S., Guillot, S., Reynard, B., Lafay, R., Debret, B., Nicollet, C., Lanari, P., Auzende, A.L., 2013. Pressure temperature estimates of the lizardite/antigorite transition in high pressure serpentinites. Lithos 178, 197-210.

Schwarzenbach, E.M., Früh-Green, G.L., Bernasconi, S.M., Alt, J.C., Plas, A., 2013. Serpentinization and carbon sequestration: A study of two ancient peridotite-hosted hydrothermal systems. Chem. Geol. 351, 115-133. https://doi.org/10.1016/j.chemgeo.2013.05.016

Sharma, S. Das, Patil, D.J., Gopalan, K., 2002. Temperature dependence of oxygen isotope fractionation of $\mathrm{CO} 2$ from magnesite-phosphoric acid reaction. Geochim. Cosmochim. Acta. https://doi.org/10.1016/S0016-7037(01)00833-X

Spandler, C., Pettke, T., Rubatto, D., 2011. Internal and External Fluid Sources for Eclogite- 
facies Veins in the Monviso Meta-ophiolite, Western Alps: Implications for Fluid Flow

in Subduction Zones. J. Petrol. 52, 1207-1236. https://doi.org/10.1093/petrology/egr025

Stöckhert, B., 2002. Stress and deformation in subduction zones: insight from the record of exhumed metamorphic rocks. Geol. Soc. London, Spec. Publ.

https://doi.org/10.1144/gsl.sp.2001.200.01.15

Tartarotti, P., Guerini, S., Rotondo, F., Festa, A., Balestro, G., Bebout, G.E., Cannaò, E., Epstein, G.S., Scambelluri, M., 2019. Superposed Sedimentary and Tectonic Block-InMatrix Fabrics in a Subducted Serpentinite Mélange (High-Pressure Zermatt Saas Ophiolite, Western Alps ). Geosciences 9, 1-29.

https://doi.org/10.3390/geosciences9080358

Treves, B., Hickmott, D., Vaggelli, G., 1995. Texture and microchemical data of oceanic hydrothermal calcite veins, northern Apennine ophicalcites. Ofioliti 20, 111-122.

Treves, B.E., Harper, G.D., 1994. Exposure of serpentinites on the ocean floor: sequence of faulting and hydrofracturing in the northern Apennine ophicalcites. Ofioliti.

Tricart, P., Lemoine, M., 1991. The Queyras ophiolite West of Monte Viso (Western Alps): Indicator of a pecular ocean floor in the mesozoic tethys. J. Geodyn. https://doi.org/10.1016/0264-3707(91)90037-F

Vissers, R.L.M., Drury, M.R., Hoogerduijn^Strating, E.H., Spiers, C.J., van der Wal, D., 1995. Mantle shear zones and their effect on lithosphere strength during continental breakup. Tectonophysics. https://doi.org/10.1016/0040-1951(95)00033-J

Vissers, R.L.M., Drury, M.R., Strating, E.H.H., der Wal, D., 1991. Shear zones in the upper mantle: A case study in an Alpine Iherzolite massif. Geology 19, 990-993.

Weissert, H., Bernoulli, D., 1984. Oxygen isotope composition of calcite in Alpine ophicarbonates: a hydrothermal or Alpine metamorphic signal? Eclogae Geol. Helv. 77/1, $29-43$.

Yamaguchi, A., Ujiie, K., Nakai, S., Kimura, G., 2012. Sources and physicochemical 
1296 characteristics of fluids along a subduction-zone megathrust: A geochemical approach 11297 using syn-tectonic mineral veins in the Mugi mélange, Shimanto accretionary complex. 2 31298 Geochemistry, Geophys. Geosystems 13. https://doi.org/10.1029/2012GC004137 
Figure 1

Click here to download high resolution image
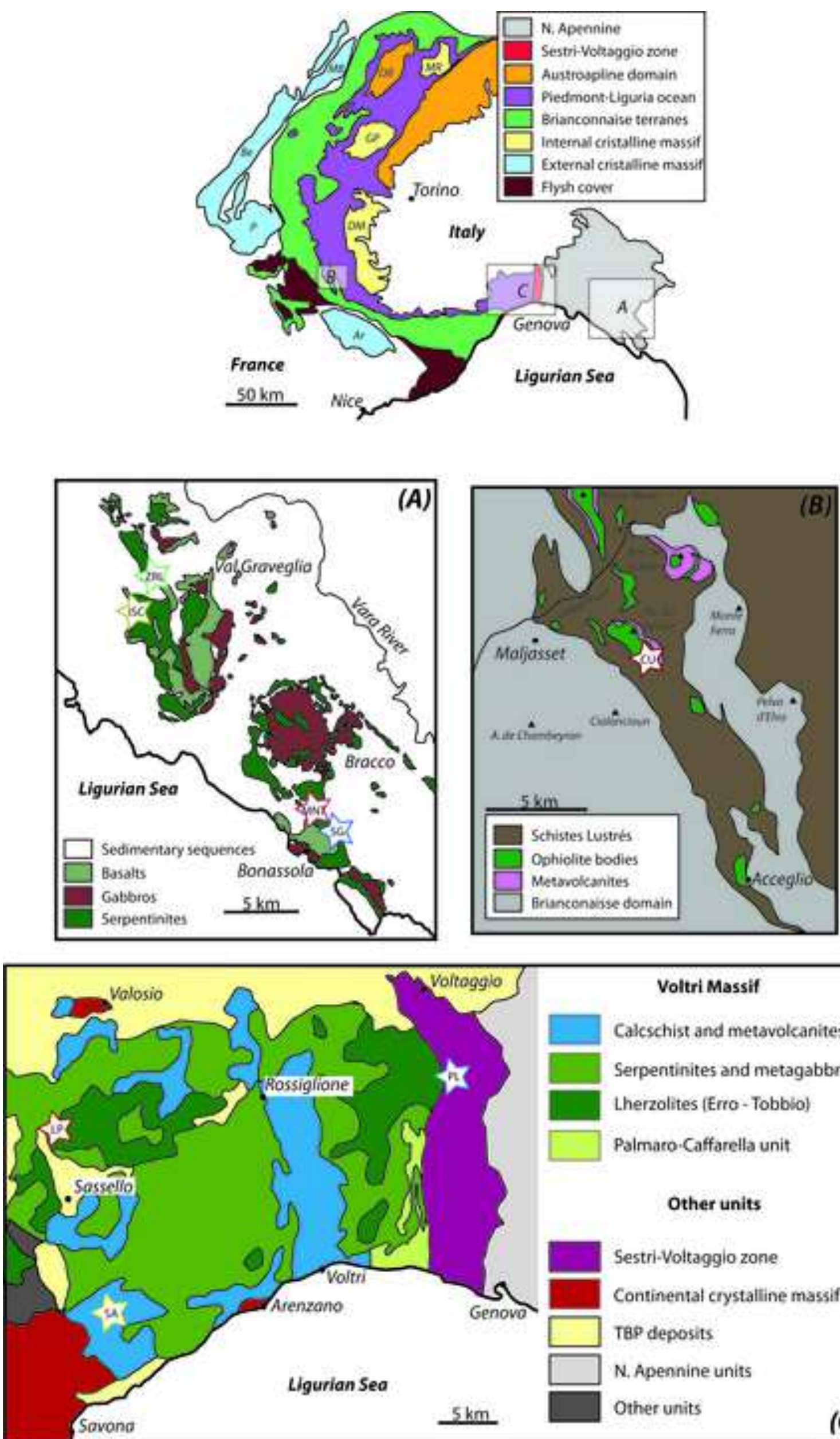

Voltri Massif

Caleschist and metavoleanites

Serpentinites and metagabbros

Lherzolites (Erro-Tobbio)

Palmaro.Caffarella unit

\section{Other units}

Sestri-Voltaggio zone

Continental crystalline massif

TBP deposits

$\mathrm{N}$, Apennine units

Other units 
Click here to download high resolution image
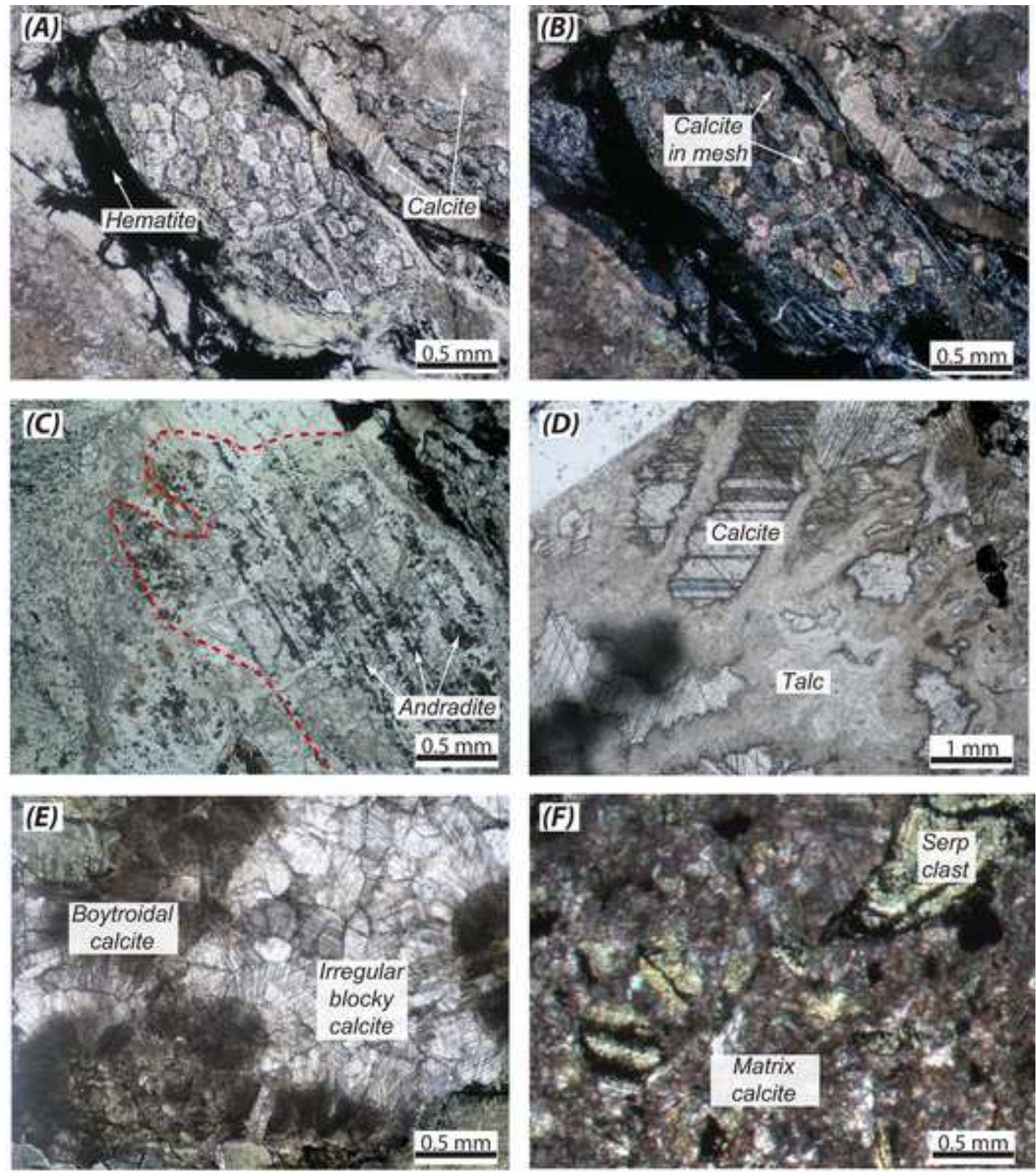


\section{Figure 3}

Click here to download high resolution image
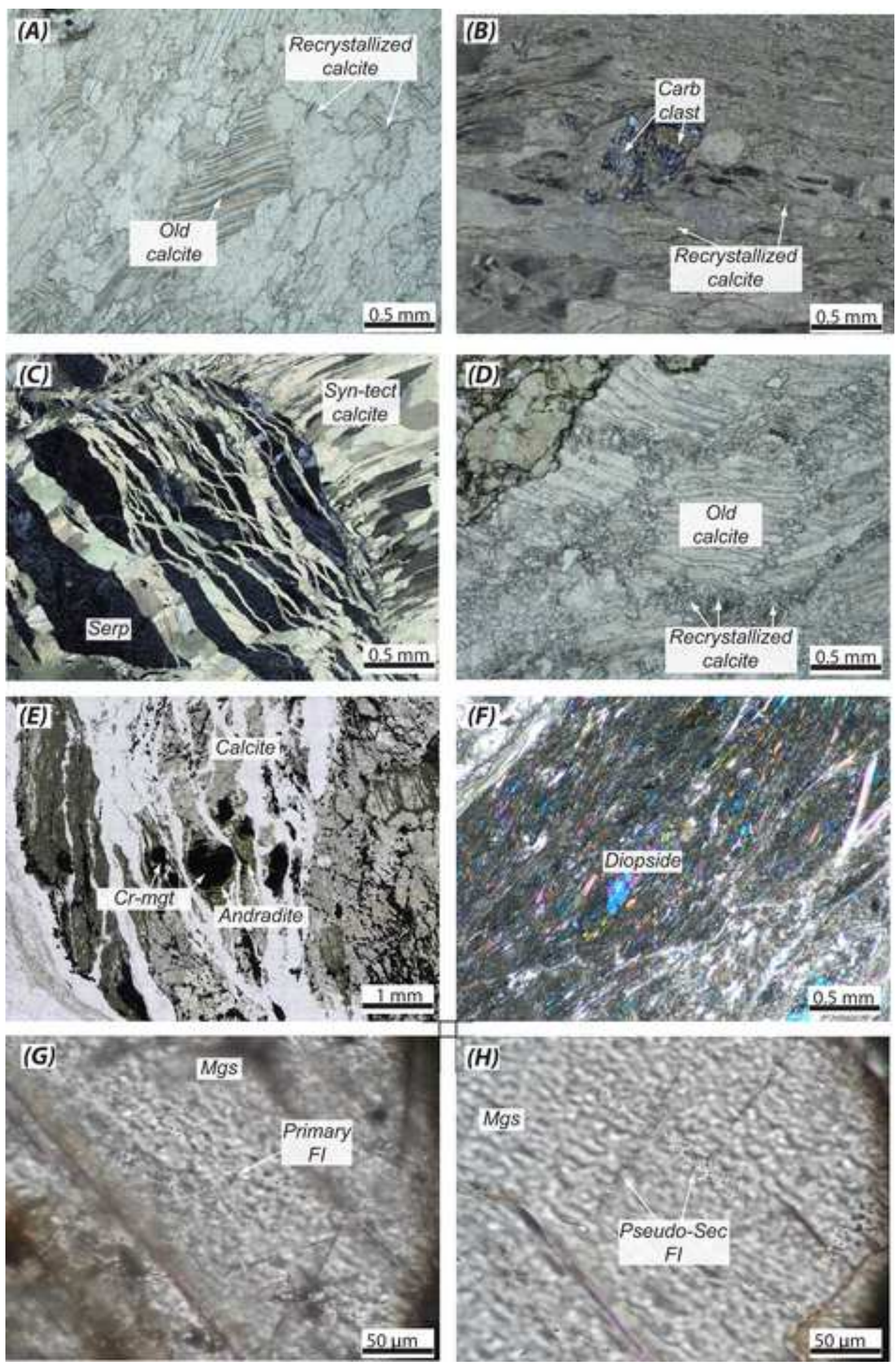

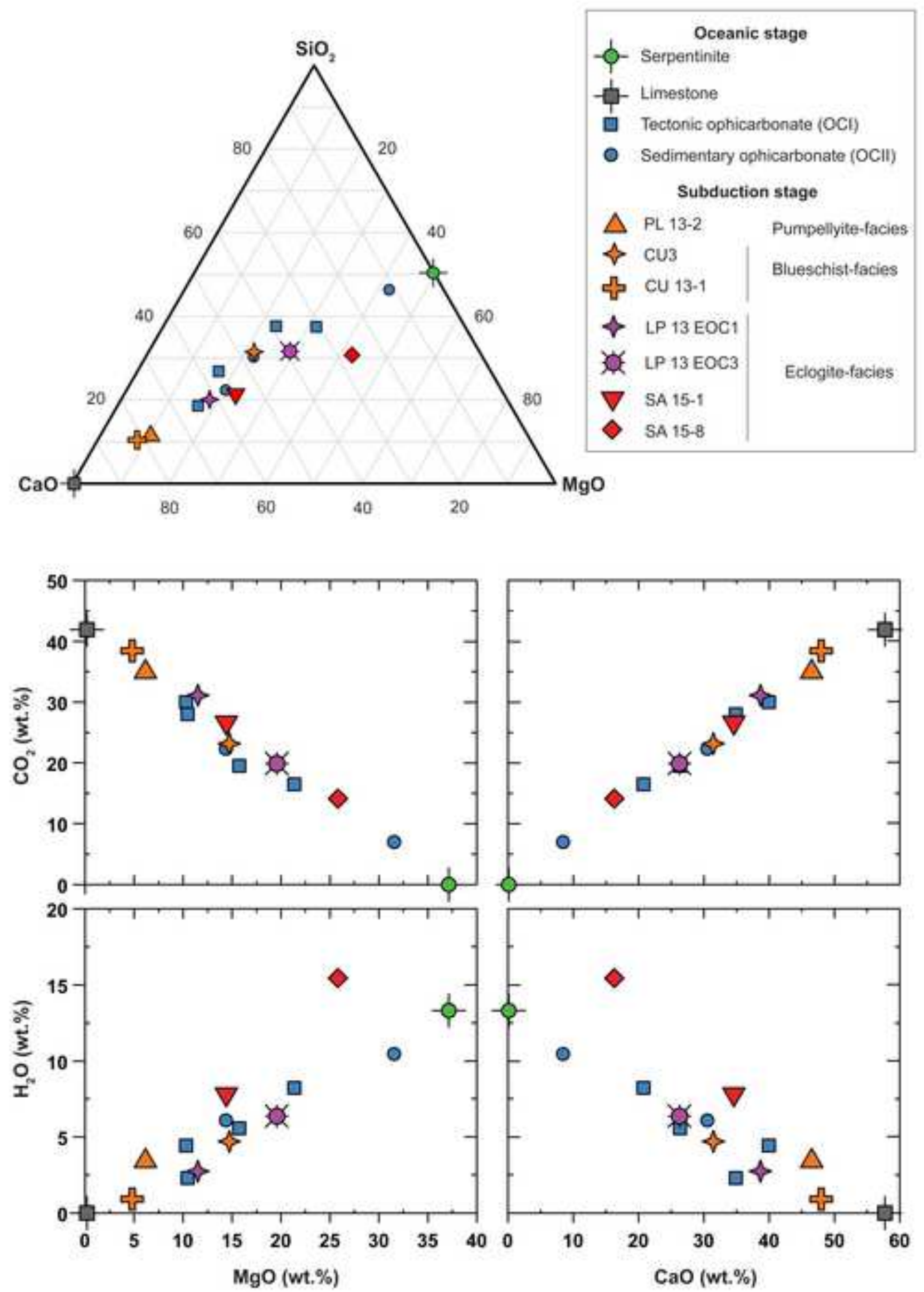

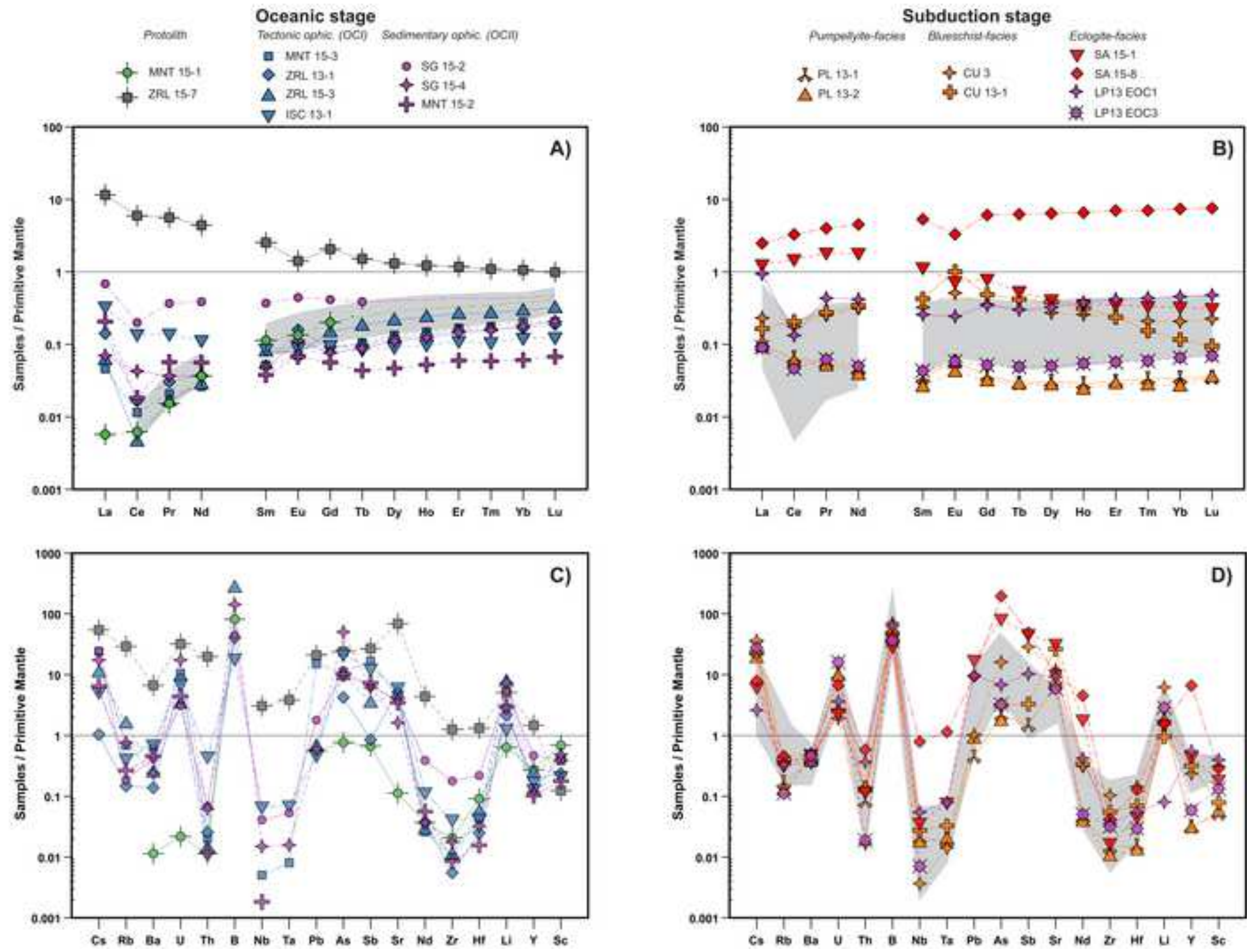

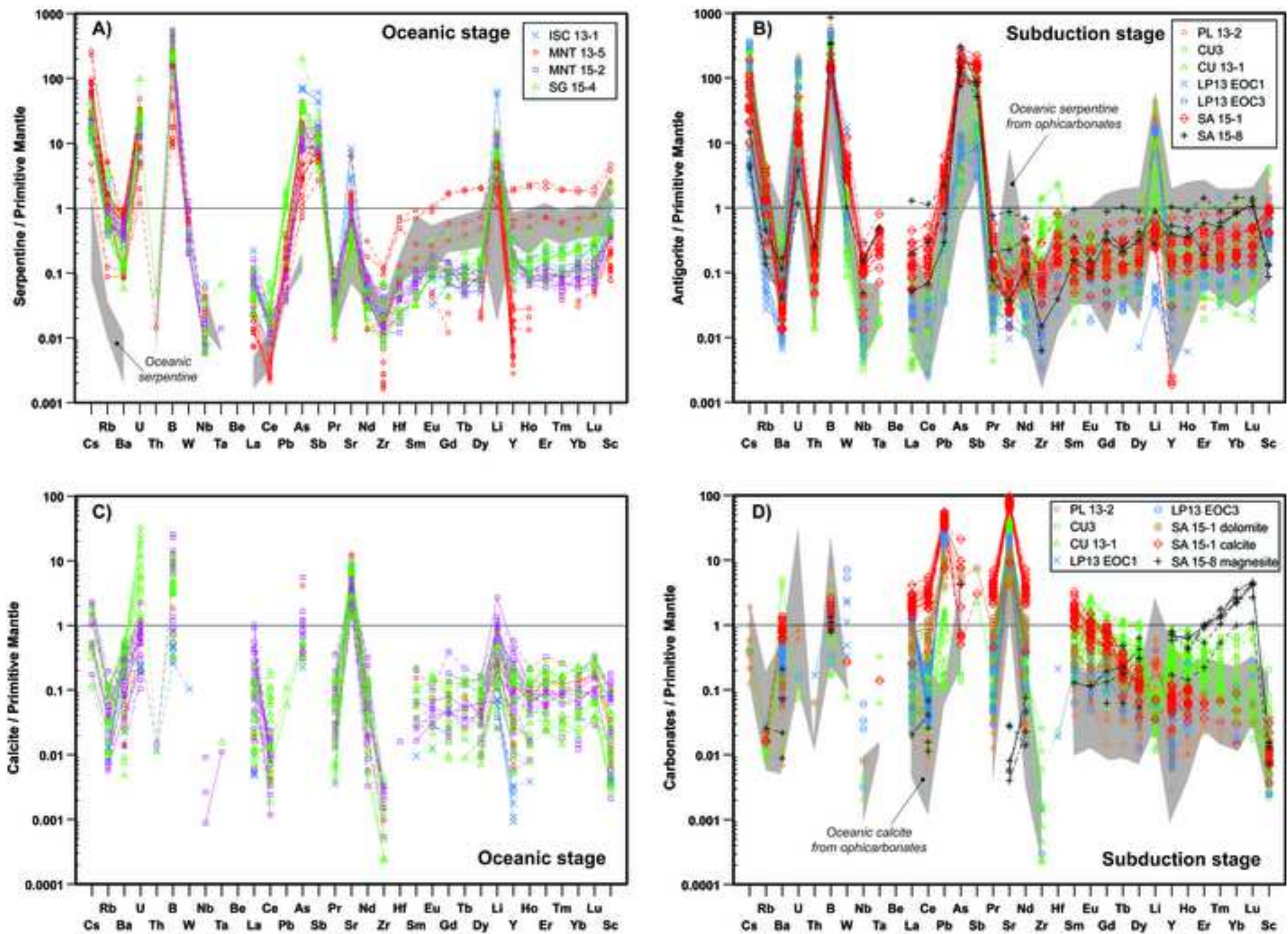


\section{Oceanic stage}

Limestone Tectonic ophic. (OCl) Sedimentary ophic. (OCII)

MNT 15-3

- 市 ZRL 15-7

$\diamond$ ZRL 13-1

$\triangle$ ZRL 15-3

$\nabla$ ISC 13-1
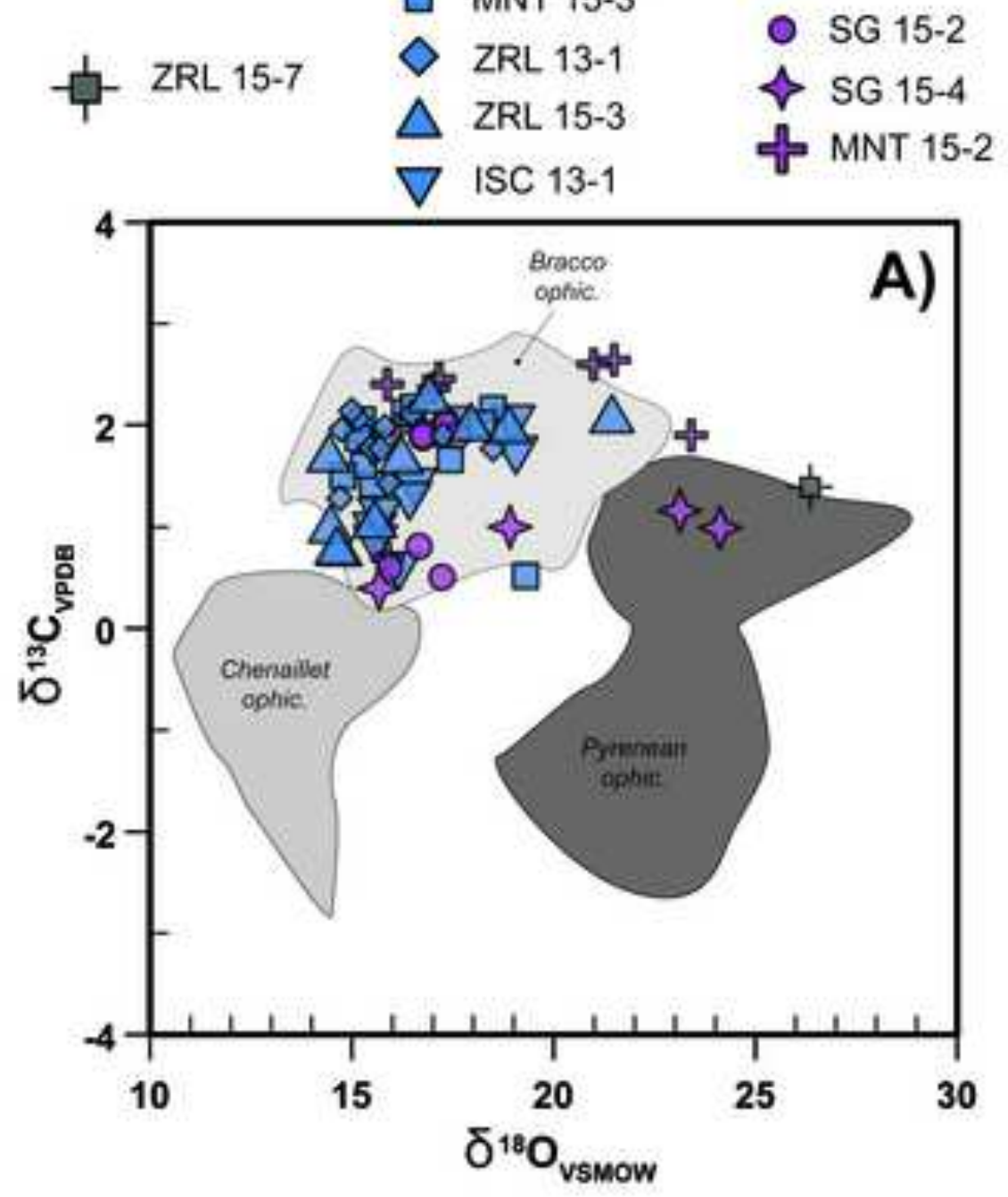

\section{Subduction stage}

Pumpellyite-facies Blueschist-facies Eclogite-facies

\&. PL 13-1

$\triangle \mathrm{PL} 13-2$

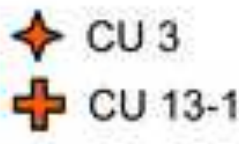

$\nabla$ SA 15-1

- SA $15-8$

\& LP13 EOC1

LP13 EOC3

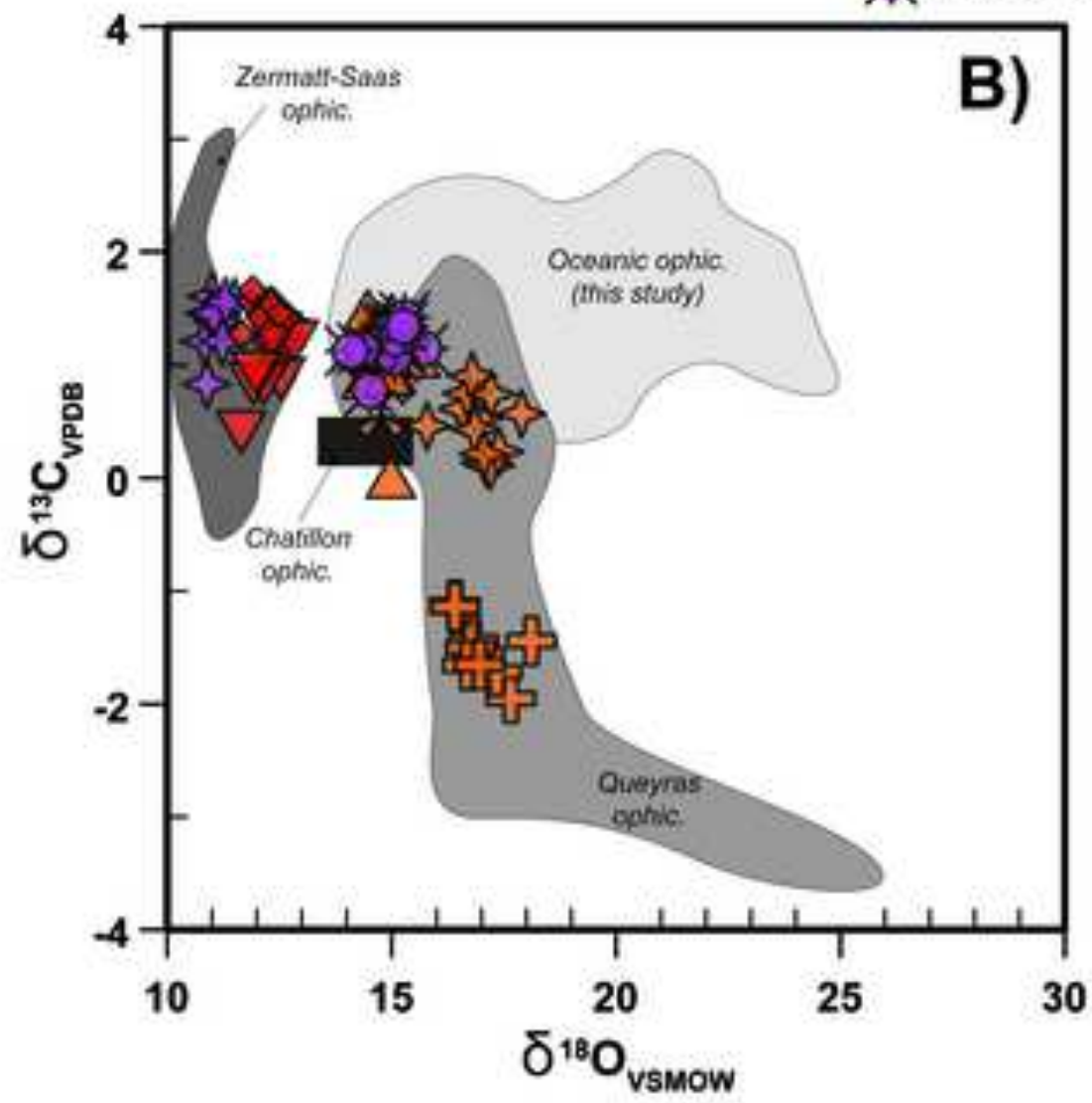


Figure 8

Click here to download high resolution image

Oceanic stage

Tectonic ophic (OCI) Sedimentary ophic. (OCII)

口 MNT $15-3$

$\diamond$ ZRL 13-1

$\triangle$ ZRL 15-3

$\nabla$ ISC 13-1

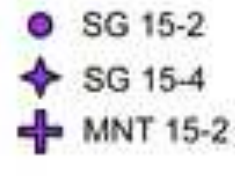

Subduction stage
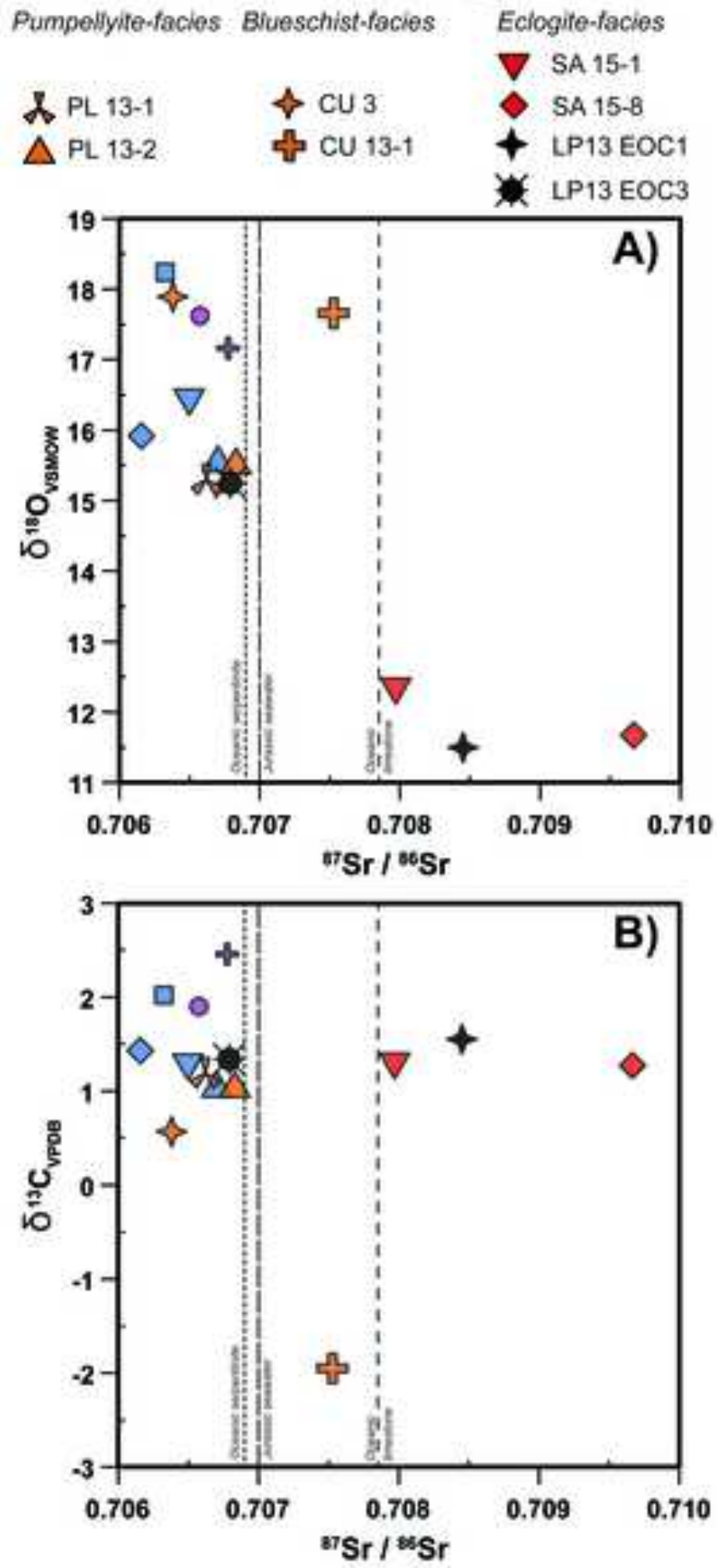


\section{Click here to download high resolution image}

(t0) fresh mantle peridotite
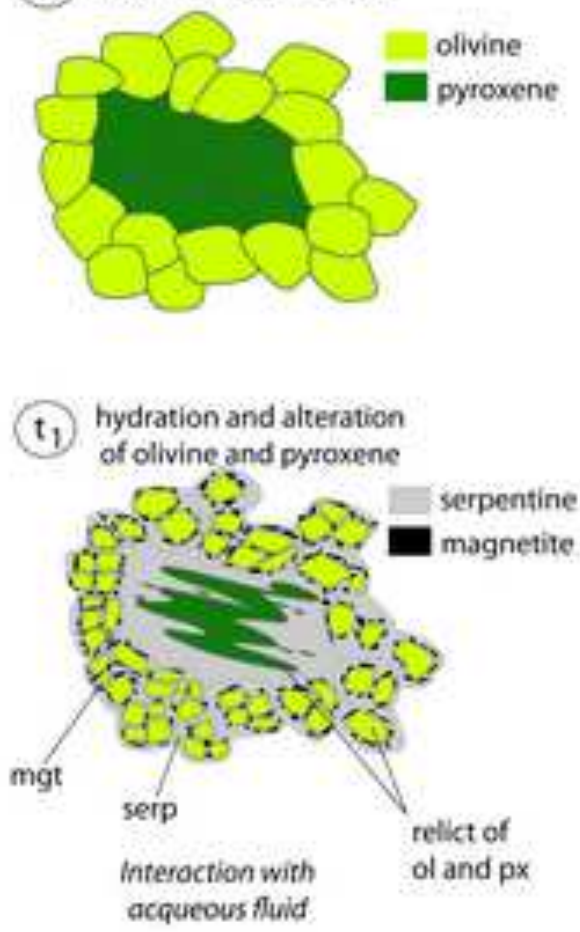

(t2) complete hydration of

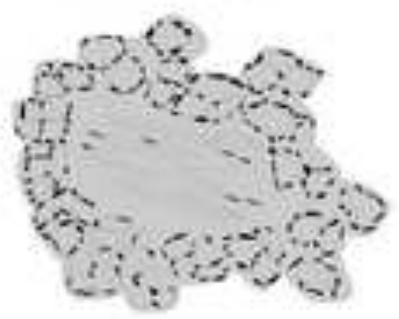

t3 carbonation of the hydrated minerals

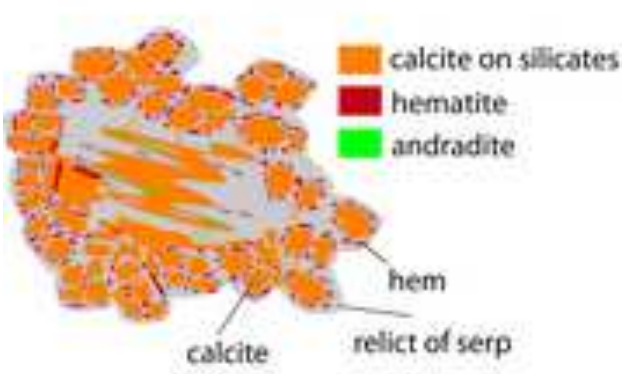

Interaction with Changing in the
$\mathrm{CO}$, enriched acqueous fluid

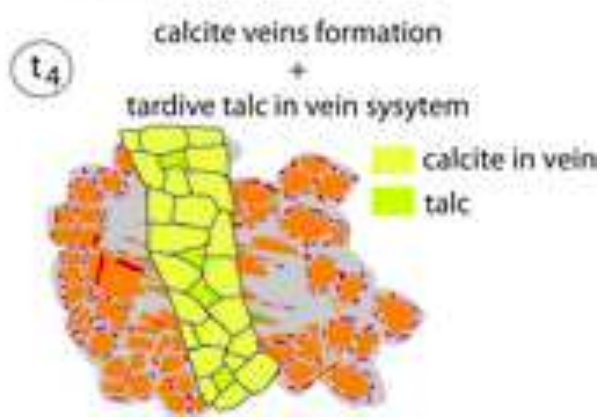




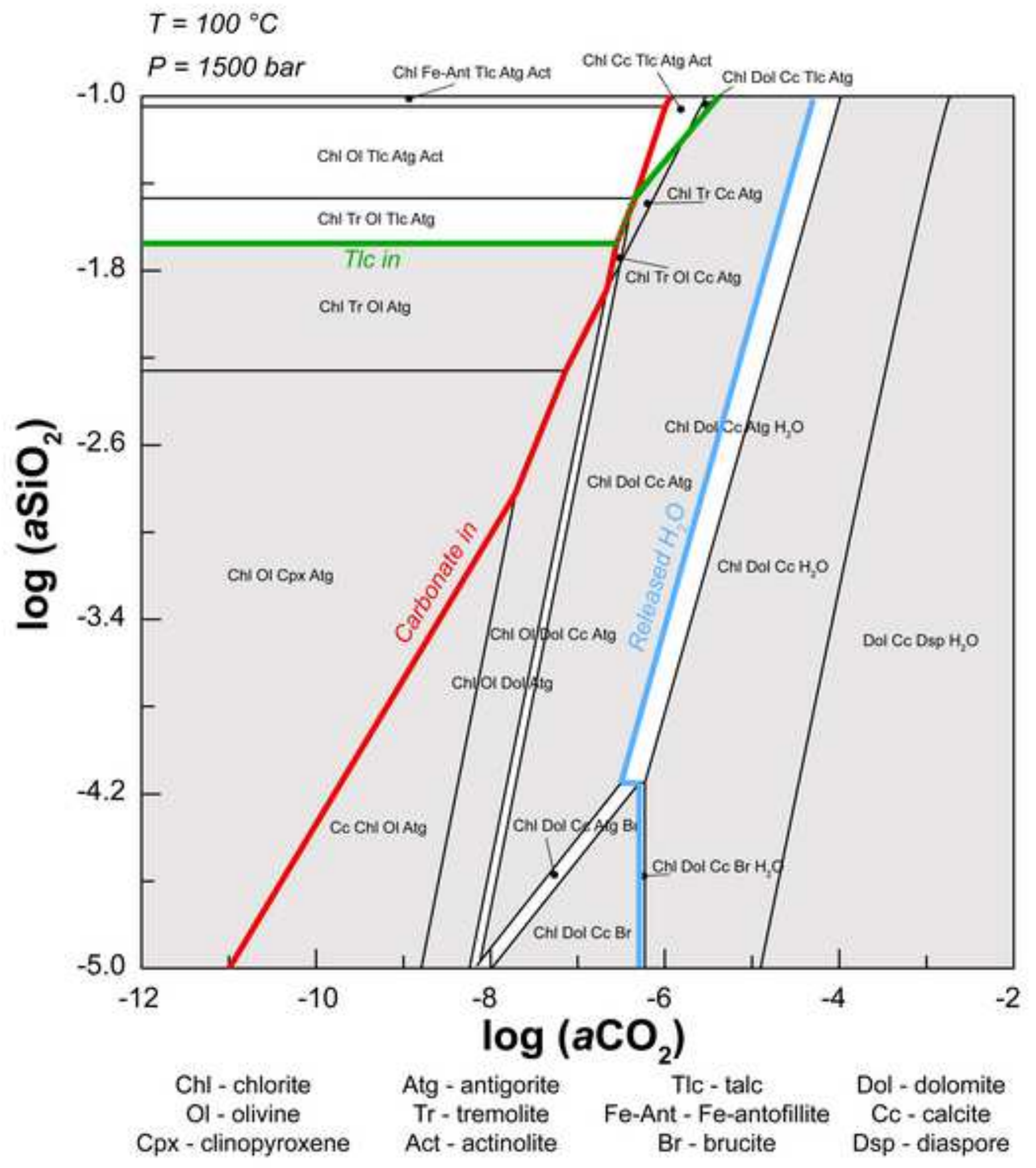



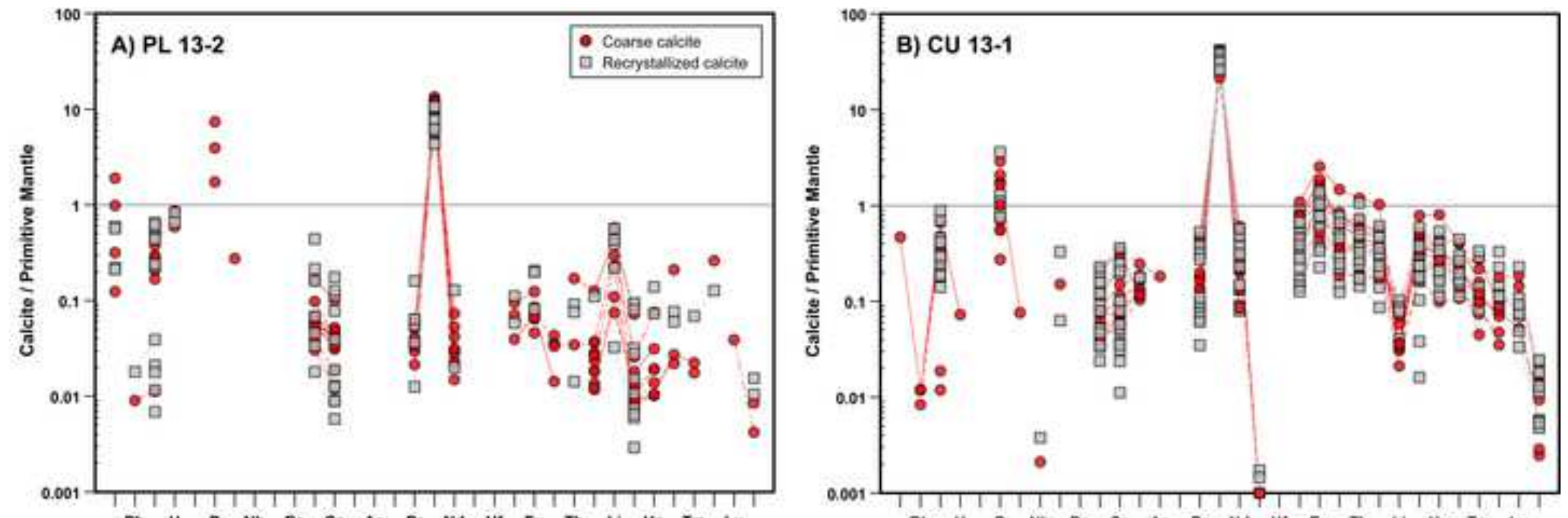

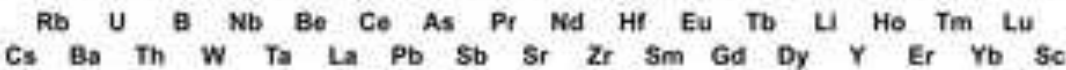

${ }^{\mathrm{Rb} U} \mathrm{~B} \mathrm{Nb} \mathrm{Be} \mathrm{Ce}$ As Pr Nd $\mathrm{HI} \mathrm{Eu} \mathrm{Tb} \mathrm{L}$ Ho $\mathrm{Tm}$ Lu
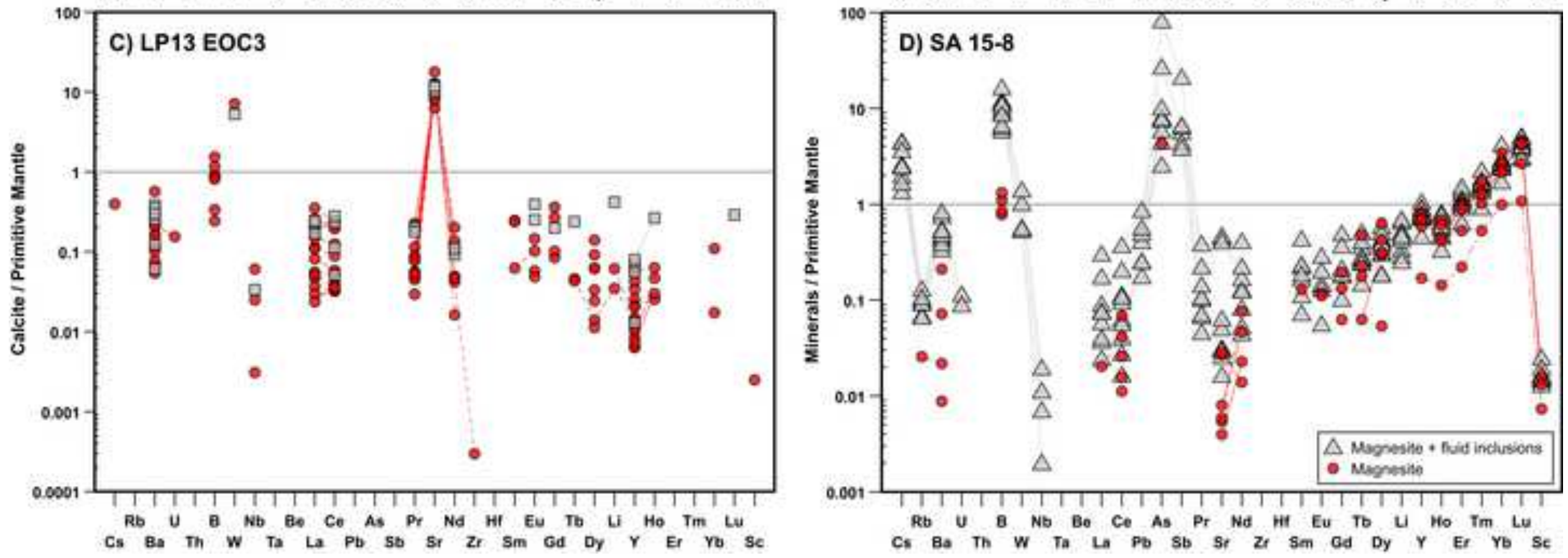


\begin{tabular}{|c|c|c|c|c|c|c|c|c|c|c|c|c|c|c|c|c|c|}
\hline & \multirow{2}{*}{$\begin{array}{l}\text { Oc. serp. } \\
\text { MNT 15-1 }\end{array}$} & \multirow{2}{*}{\begin{tabular}{|c|} 
Limestone \\
ZRL 15-7
\end{tabular}} & \multicolumn{4}{|c|}{ Oc. tectonic ophicarbonates } & \multicolumn{3}{|c|}{ Oc. Sedimentary ophicarbonates } & \multicolumn{4}{|c|}{ Prograde ophicarbonates } & \multicolumn{4}{|c|}{ Eclogite facies ophicarbonates } \\
\hline & & & | MNT 13-5 & ZRL 13-1 & ZRL 15-3 & ISC 13-1 & SG 15-4 & SG 15-2 & MNT 15-2 & PL 13-1 & PL 13-2 & CU 3 & CU 13-1 & SA 15-1 & SA 15-8 & LP13 EOC1 & LP13 EOC3 \\
\hline $\begin{array}{l}\text { GPS sample } \\
\text { location }\end{array}$ & $\begin{array}{c}N 44.19811 \\
E 9.58860\end{array}$ & $\begin{array}{c}N 44.34558 \\
E 9.45221\end{array}$ & $\begin{array}{l}N 44.19811 \\
F 05890\end{array}$ & $\begin{array}{l}N 44.34558 \\
F 0.4527\end{array}$ & $\begin{array}{l}N 44.34558 \\
F .45221\end{array}$ & $\begin{array}{l}N 44.32808 \\
F 044154\end{array}$ & $\begin{array}{l}N 44.19654 \\
F 058015\end{array}$ & $\begin{array}{l}N 44.19654 \\
F 058015\end{array}$ & $\begin{array}{l}N 44.19811 \\
F 05850\end{array}$ & $N 44.53202$ & $N 44.53202$ & $N 44.58542$ & $N 44.58542$ & $\begin{array}{l}N 44.40907 \\
N 8.505\end{array}$ & $\begin{array}{l}N 44.40907 \\
+58.505\end{array}$ & N 44.55364 & N 44.55364 \\
\hline $\mathrm{SiO}_{2}$ & 37.80 & 0.02 & 25.40 & $\frac{L 9.45271}{11.46}$ & 25.28 & 16.63 & $\begin{array}{l}E 9.38915 \\
34.53 \\
\end{array}$ & $\frac{19.5015}{19.54}$ & $\begin{array}{l}E 9.58800 \\
14.04\end{array}$ & E 88.181 & $\begin{array}{c}\text { E } 8.1 .181 \\
6.96 \\
\end{array}$ & $\begin{array}{c}E 6.92014 \\
21.22\end{array}$ & E6.92014 & $E 8.54205$ & E8.54205 & $E 8.44636$ & E 8.44636 \\
\hline $\mathrm{Al}_{2} \mathrm{O}_{3}$ & 1.69 & 0.01 & 1.09 & 0.65 & 1.57 & 1.27 & 1.10 & 1.71 & 0.54 & & 0.16 & 1.14 & 0.24 & 0.25 & 1.34 & 1.03 & 0.52 \\
\hline $\mathrm{Fe}_{2} \mathrm{O}_{3}$ (Tot) & 8.37 & 0.03 & 5.14 & 3.43 & 5.92 & 5.56 & 6.53 & 5.26 & 3.17 & & 1.20 & 3.28 & 1.59 & 2.92 & 8.47 & 4.97 & 2.67 \\
\hline MnO & 0.123 & 0.080 & 0.071 & 0.080 & 0.098 & 0.093 & 0.124 & 0.092 & 0.100 & & 0.042 & 0.124 & 0.114 & 0.121 & 0.413 & 0.063 & 0.056 \\
\hline MgO & 37.14 & 0.17 & 15.75 & 10.29 & 21.34 & 10.45 & 31.57 & 14.38 & 12.90 & & 6.16 & 14.71 & 4.81 & 14.41 & 25.82 & 19.58 & 11.51 \\
\hline $\mathrm{CaO}$ & 0.12 & 57.73 & 26.35 & 39.95 & 20.77 & 34.91 & 8.42 & 30.52 & 35.96 & & 46.51 & 31.46 & 47.96 & 34.57 & 16.28 & 26.28 & 38.67 \\
\hline $\mathrm{Na}_{2} \mathrm{O}$ & $<0.01$ & 0.02 & 0.07 & 0.01 & $<0.01$ & 0.03 & $<0.01$ & 0.03 & $<0.01$ & & $<0.01$ & 0.01 & $<0.01$ & $<0.01$ & 0.04 & $<0.01$ & $<0.01$ \\
\hline $\mathrm{K}_{2} \mathrm{O}$ & $<0.01$ & $<0.01$ & $<0.01$ & $<0.01$ & 0.02 & $<0.01$ & $<0.01$ & $<0.01$ & $<0.01$ & & $<0.01$ & $<0.01$ & $<0.01$ & $<0.01$ & 0.01 & $<0.01$ & $<0.01$ \\
\hline $\mathrm{TiO}_{2}$ & 0.045 & 0.020 & 0.026 & 0.013 & 0.030 & 0.013 & 0.023 & 0.051 & 0.007 & & 0.003 & 0.036 & 0.013 & 0.008 & 0.043 & 0.019 & 0.007 \\
\hline $\mathbf{P}_{2} \mathbf{O}_{5}$ & $<0.01$ & $<0.01$ & 0.02 & 0.03 & 0.02 & 0.02 & 0.03 & 0.03 & 0.03 & & 0.01 & $<0.01$ & $<0.01$ & 0.06 & 0.04 & 0.03 & 0.03 \\
\hline $\mathrm{H}_{2} \mathrm{O}^{*}$ & 13.32 & $<0.01$ & 5.58 & 4.43 & 8.22 & 2.30 & 10.46 & 6.10 & n.d. & & 3.51 & 4.71 & 0.92 & 7.70 & 15.44 & 6.36 & 2.75 \\
\hline $\mathrm{CO}_{2}$ & $<0.01$ & 41.88 & 19.50 & 30.00 & 16.50 & 28.00 & 7.00 & 22.30 & n.d. & & 35.20 & 23.20 & 38.40 & 26.40 & 14.10 & 19.90 & 31.10 \\
\hline LOI & 13.32 & 41.88 & 25.08 & 34.43 & 24.72 & 30.30 & 17.46 & 28.40 & 32.97 & & 38.71 & 27.91 & 39.32 & 34.10 & 29.54 & 26.26 & 33.85 \\
\hline Total & 98.61 & 58.12 & 99.01 & 100.30 & 99.79 & 99.28 & 99.79 & 100.00 & 99.73 & & 99.75 & 99.90 & 100.20 & 99.49 & 100.70 & 99.50 & 99.89 \\
\hline $\mathbf{L i}$ & 1.24 & 9.94 & 5.47 & 4.19 & 15.30 & 2.46 & 14.29 & 10.57 & 5.79 & 3.68 & 3.46 & 12.13 & 1.85 & 2.90 & 3.04 & 0.16 & 5.57 \\
\hline $\mathbf{B}^{*}$ & 24.6 & 22.6 & n.d. & 12.2 & 82.1 & 5.4 & 13.4 & 42.9 & n.d. & 17.4 & 16.2 & 21.1 & 10.9 & 8.6 & 12.8 & 18.9 & 10.9 \\
\hline Sc & 14.9 & 2.22 & 7.13 & 4.41 & 8.42 & 3.89 & 9.39 & 7.38 & 3.26 & 0.97 & 1.06 & 5.81 & 1.43 & 3.30 & 5.36 & 7.22 & 2.44 \\
\hline $\mathbf{v}$ & 57 & 18 & 32 & 24 & 48 & 30 & 41 & 22 & 16 & 5 & 5 & 29 & 6 & 12 & 30 & 30 & 12 \\
\hline Co & 109.0 & 1.7 & 55.0 & 23.0 & 48.0 & 52.0 & 101.0 & 53.0 & 34.0 & 20.0 & 19.0 & 48.0 & 8.9 & 27.7 & 53.3 & 49.0 & 36.9 \\
\hline $\mathbf{N i}$ & 2200 & 13 & 1179 & 600 & 1015 & 1150 & 2000 & 880 & 870 & 350 & 350 & 790 & 160 & 430 & 500 & 950 & 750 \\
\hline $\mathrm{Cu}$ & 44.0 & 26.0 & 39.0 & 39.0 & 45.0 & 12.2 & 17.0 & 25.0 & 23.0 & 100.0 & 13.6 & 22.9 & 15.5 & 21.7 & 22.0 & 90.4 & 17.8 \\
\hline $\mathbf{Z n}$ & 62.00 & 33.00 & 28.00 & 33.00 & 35.00 & 32.17 & 31.70 & 40.00 & 23.00 & 49.00 & 13.69 & 23.94 & 14.77 & 18.46 & 43.59 & 40.53 & 17.08 \\
\hline $\mathbf{G a}$ & 1.443 & 2.795 & 0.974 & 0.604 & 1.204 & 0.862 & 1.119 & 1.219 & 0.428 & 0.096 & 0.106 & 0.841 & 0.215 & 0.389 & 2.759 & 0.974 & 0.296 \\
\hline As & 0.038 & 1.202 & 0.551 & 0.212 & 0.500 & 1.072 & 2.504 & 0.504 & 0.515 & 0.109 & 0.087 & 0.803 & 0.155 & 4.071 & 9.737 & 0.339 & 0.162 \\
\hline $\mathbf{R b}$ & b.d.I. & 17.5 & 0.412 & 0.088 & 0.958 & 0.245 & 0.458 & 0.111 & 0.158 & 0.101 & 0.076 & 0.217 & 0.244 & 0.189 & 0.274 & 0.198 & 0.067 \\
\hline $\mathbf{S r}$ & 2.23 & 1365 & 86.1 & 103 & 97.1 & 120 & 32.1 & 74.3 & 68.9 & 137 & 155 & 236 & 525 & 633 & 212 & 184 & 117 \\
\hline $\mathbf{Y}$ & 1.370 & 7.170 & 0.665 & 0.919 & 1.213 & 0.630 & 0.571 & 2.297 & 0.438 & 0.155 & 0.149 & 1.166 & 1.550 & 2.155 & 32.438 & 2.716 & 0.291 \\
\hline $\mathbf{Z r}$ & 0.212 & 14.640 & 0.120 & 0.057 & 0.134 & 0.477 & 0.206 & 2.068 & 0.089 & 0.171 & 0.124 & 1.215 & 0.646 & 0.194 & 0.492 & 0.407 & 0.370 \\
\hline Nb & b.d.l. & 2.410 & 0.008 & b.d.I. & b.d.I. & 0.056 & 0.012 & 0.036 & 0.001 & 0.020 & 0.018 & 0.007 & 0.026 & 0.032 & 0.621 & 0.047 & 0.009 \\
\hline Cd & 0.034 & 0.447 & 0.101 & 0.245 & 0.099 & 0.227 & 0.090 & 0.180 & 0.160 & 0.072 & 0.072 & 0.184 & 0.043 & 0.168 & 0.139 & 0.073 & 0.060 \\
\hline Sb & 0.004 & 0.148 & 0.092 & 0.005 & 0.019 & 0.068 & 0.034 & 0.035 & 0.040 & 0.008 & b.d.l. & 0.158 & 0.018 & 0.254 & 0.269 & 0.056 & b.d.I. \\
\hline Cs & b.d.I. & 1.14 & 0.505 & 0.022 & 0.233 & 0.107 & 0.366 & 0.515 & 0.136 & 0.526 & 0.402 & 0.763 & 0.491 & 0.128 & 0.167 & 0.055 & 0.585 \\
\hline Ba & 0.08 & 44.04 & 4.12 & 0.91 & 1.65 & 4.59 & 1.60 & 2.82 & 3.04 & 2.59 & 2.50 & 3.23 & 2.57 & 3.16 & 3.27 & 2.33 & 3.06 \\
\hline $\mathbf{L a}$ & 0.004 & 7.477 & 0.030 & 0.092 & 0.040 & 0.213 & 0.046 & 0.445 & 0.133 & 0.061 & 0.069 & 0.150 & 0.106 & 0.815 & 1.609 & 0.609 & 0.059 \\
\hline $\mathrm{Ce}$ & 0.010 & 9.962 & 0.019 & 0.028 & 0.008 & 0.228 & 0.072 & 0.334 & 0.030 & 0.110 & 0.097 & 0.295 & 0.345 & 2.470 & 5.498 & 0.223 & 0.078 \\
\hline Pr & 0.004 & 1.426 & 0.005 & 0.008 & 0.004 & 0.035 & 0.009 & 0.093 & 0.014 & 0.014 & 0.013 & 0.064 & 0.070 & 0.460 & 1.013 & 0.110 & 0.016 \\
\hline Nd & 0.046 & 5.494 & 0.033 & 0.047 & 0.036 & 0.141 & 0.046 & 0.484 & 0.070 & 0.056 & 0.048 & 0.392 & 0.426 & 2.255 & 5.640 & 0.524 & 0.063 \\
\hline Sm & 0.046 & 1.031 & 0.021 & 0.021 & 0.033 & 0.035 & 0.019 & 0.150 & 0.015 & 0.014 & 0.011 & 0.131 & 0.172 & 0.460 & 2.153 & 0.105 & 0.018 \\
\hline Eu & 0.021 & 0.218 & 0.011 & 0.024 & 0.012 & 0.014 & 0.017 & 0.069 & 0.010 & 0.009 & 0.006 & 0.079 & 0.155 & 0.113 & 0.508 & 0.038 & 0.009 \\
\hline Gd & 0.109 & 1.123 & 0.050 & 0.050 & 0.081 & 0.052 & 0.041 & 0.225 & 0.031 & 0.020 & 0.017 & 0.192 & 0.263 & 0.430 & 3.299 & 0.188 & 0.028 \\
\hline $\mathbf{T b}$ & 0.024 & 0.150 & 0.010 & 0.010 & 0.018 & 0.008 & 0.009 & 0.038 & 0.004 & 0.003 & 0.003 & 0.030 & 0.042 & 0.053 & 0.619 & 0.030 & 0.005 \\
\hline Dy & 0.191 & 0.884 & 0.090 & 0.081 & 0.147 & 0.061 & 0.075 & 0.270 & 0.032 & 0.021 & 0.019 & 0.185 & 0.258 & 0.277 & 4.311 & 0.218 & 0.034 \\
\hline Ho & 0.047 & 0.183 & 0.022 & 0.020 & 0.036 & 0.015 & 0.018 & 0.062 & 0.008 & 0.004 & 0.004 & 0.038 & 0.047 & 0.053 & 0.979 & 0.056 & 0.008 \\
\hline Er & 0.146 & 0.516 & 0.074 & 0.068 & 0.117 & 0.048 & 0.064 & 0.191 & 0.026 & 0.014 & 0.013 & 0.104 & 0.104 & 0.153 & 3.077 & 0.184 & 0.025 \\
\hline Tm & 0.024 & 0.075 & 0.012 & 0.011 & 0.019 & 0.007 & 0.011 & 0.029 & 0.004 & 0.002 & 0.002 & 0.014 & 0.010 & 0.023 & 0.476 & 0.030 & 0.004 \\
\hline $\mathbf{Y b}$ & 0.168 & 0.469 & 0.090 & 0.074 & 0.130 & 0.053 & 0.080 & 0.194 & 0.027 & 0.015 & 0.012 & 0.092 & 0.051 & 0.144 & 3.267 & 0.202 & 0.029 \\
\hline Lu & 0.028 & 0.067 & 0.014 & 0.013 & 0.022 & 0.008 & 0.014 & 0.032 & 0.005 & 0.002 & 0.002 & 0.015 & 0.006 & 0.021 & 0.513 & 0.032 & 0.005 \\
\hline Hf & 0.026 & 0.371 & 0.012 & 0.007 & 0.016 & 0.012 & 0.009 & 0.062 & 0.004 & 0.004 & 0.004 & 0.040 & 0.020 & 0.013 & 0.036 & 0.016 & 0.008 \\
\hline Ta & b.d.I. & 0.142 & 0.001 & b.d.I. & b.d.I. & 0.003 & 0.001 & 0.002 & b.d.l. & 0.001 & 0.001 & 0.001 & 0.001 & 0.003 & 0.042 & 0.003 & b.d.l. \\
\hline $\mathbf{P b}$ & 0.084 & 3.162 & 2.269 & b.d.I. & 0.101 & 0.069 & 0.089 & 0.267 & b.d.l. & 0.067 & 0.136 & 0.153 & b.d.I. & 2.602 & 1.410 & 1.457 & b.d.l. \\
\hline Th & 0.001 & 1.567 & 0.002 & 0.002 & 0.001 & 0.035 & 0.005 & 0.005 & 0.001 & 0.007 & 0.011 & 0.001 & 0.011 & 0.009 & 0.046 & 0.029 & 0.001 \\
\hline $\mathbf{U}$ & 0.001 & 0.740 & 0.242 & 0.197 & 0.077 & 0.158 & 0.400 & 0.071 & 0.101 & 0.234 & 0.221 & 0.044 & 0.059 & 0.052 & 0.154 & 0.083 & 0.368 \\
\hline
\end{tabular}

- data peformed at TIMS
b.I. - below detection limits 
Table 2. In situ major (in wt.\%) and trace element (in ppm) composition of serpentine minerals

\begin{tabular}{|c|c|c|c|c|c|c|c|}
\hline & \multicolumn{6}{|c|}{ MNT 15-1 } & \multirow{3}{*}{$\frac{\text { MNT }}{\text { clast }(r}$} \\
\hline & \multirow{2}{*}{\multicolumn{2}{|c|}{$\begin{array}{c}\text { ifter pyroxene }(n=11, \\
s d\end{array}$}} & \multicolumn{2}{|c|}{ after olivine $(n=8)$} & \multicolumn{2}{|c|}{$\operatorname{mesh}(n=3)$} & \\
\hline & & & & $s d$ & & $s d$ & \\
\hline $\mathrm{SiO}_{2}$ & 38.07 & 0.91 & 40.35 & 0.71 & 35.31 & 0.92 & 49.35 \\
\hline $\mathrm{TiO}_{2}$ & 0.10 & 0.05 & 0.03 & 0.02 & 0.03 & 0.00 & 0.02 \\
\hline $\mathrm{Al}_{2} \mathrm{O}_{3}$ & 3.21 & 0.92 & 0.89 & 0.32 & 0.59 & 0.05 & 1.61 \\
\hline $\mathrm{FeO}$ & 4.80 & 1.08 & 5.04 & 0.59 & 12.81 & 2.16 & 6.36 \\
\hline MnO & 0.14 & 0.02 & 0.08 & 0.01 & 0.09 & 0.00 & 0.12 \\
\hline MgO & 41.62 & 0.77 & 41.55 & 0.73 & 39.14 & 1.23 & 26.29 \\
\hline $\mathrm{CaO}$ & 0.06 & 0.02 & 0.06 & 0.01 & 0.04 & 0.00 & 4.14 \\
\hline $\mathrm{Na}_{2} \mathrm{O}$ & $<0.01$ & & $<0.01$ & & $<0.01$ & & 0.11 \\
\hline $\mathbf{K}_{2} \mathbf{O}$ & $<0.01$ & & $<0.01$ & & $<0.01$ & & 0.60 \\
\hline \multirow[t]{2}{*}{ Total } & 88.00 & & 87.98 & & 88.00 & & 88.12 \\
\hline & \multicolumn{2}{|c|}{$n=10$} & \multicolumn{2}{|c|}{$n=8$} & \multicolumn{2}{|c|}{$n=3$} & $n=$ \\
\hline $\mathbf{L i}$ & 2.0 & 2.4 & 0.26 & 0.18 & 0.061 & 0.037 & 9.3 \\
\hline B & 50 & 32 & 36 & 11 & 32 & 13 & 43 \\
\hline Sc & 32 & 12 & 11 & 5 & 7.0 & 0.8 & 3.6 \\
\hline $\mathbf{V}$ & 152 & 79 & 27 & 23 & 16 & 1 & 33 \\
\hline $\mathrm{Cr}$ & 5900 & 2000 & 700 & 600 & 130 & 70 & 1200 \\
\hline Co & 13 & 8 & 15 & 4 & 86 & 38 & 132 \\
\hline $\mathbf{N i}$ & 380 & 150 & 1600 & 400 & 2200 & 600 & 3100 \\
\hline $\mathbf{Z n}$ & 12 & 5 & 9.2 & 1.5 & 8.8 & 1.0 & 34 \\
\hline As & 0.008 & 0.002 & $<0.060$ & & 0.007 & 0.002 & 0.46 \\
\hline $\mathbf{R b}$ & 0.011 & 0.005 & $<0.023$ & & 0.008 & 0.001 & 0.97 \\
\hline $\mathbf{S r}$ & 2.5 & 1.4 & 2.2 & 0.5 & 1.8 & 0.1 & 22 \\
\hline $\mathbf{Y}$ & 2.0 & 0.8 & 1.7 & 1.0 & 1.4 & 0.2 & 0.083 \\
\hline $\mathbf{Z r}$ & 0.27 & 0.02 & 0.25 & 0.05 & 0.17 & 0.03 & 0.11 \\
\hline $\mathrm{Nb}$ & 0.020 & 0.007 & $<0.017$ & & $<0.001$ & & 0.013 \\
\hline In & 0.018 & 0.004 & $<0.014$ & & 0.006 & 0.001 & 0.012 \\
\hline $\mathbf{S b}$ & $<0.004$ & & $<0.072$ & & $<0.004$ & & 0.045 \\
\hline Cs & 0.010 & 0.011 & $<0.019$ & & 0.002 & 0.000 & 1.5 \\
\hline $\mathbf{B a}$ & 0.032 & 0.024 & $<0.126$ & & 0.028 & 0.004 & 4.2 \\
\hline $\mathbf{L a}$ & 0.002 & 0.001 & $<0.013$ & & 0.001 & & 0.012 \\
\hline $\mathrm{Ce}$ & 0.012 & 0.004 & $<0.020$ & & 0.007 & 0.000 & 0.007 \\
\hline Pr & 0.006 & 0.003 & $<0.011$ & & 0.003 & 0.000 & 0.005 \\
\hline Nd & 0.082 & 0.028 & 0.12 & 0.03 & 0.052 & 0.005 & 0.079 \\
\hline Sm & 0.078 & 0.038 & 0.21 & 0.07 & 0.053 & 0.012 & 0.13 \\
\hline $\mathbf{E u}$ & 0.036 & 0.018 & $<0.028$ & & 0.025 & 0.005 & 0.051 \\
\hline Gd & 0.19 & 0.07 & 0.14 & 0.03 & 0.12 & 0.02 & 0.067 \\
\hline $\mathbf{T b}$ & 0.039 & 0.018 & 0.030 & 0.011 & 0.025 & 0.003 & 0.081 \\
\hline Dy & 0.33 & 0.13 & 0.29 & 0.10 & 0.21 & 0.03 & 0.29 \\
\hline
\end{tabular}


Table 3. In situ major (in wt.\%) and trace element (in ppm) composition of carbonate minerals fron

\begin{tabular}{|c|c|c|c|c|c|c|c|c|}
\hline & \multicolumn{4}{|c|}{ MNT 13-5 } & \multicolumn{4}{|c|}{ ISC 13-1 } \\
\hline & \multirow{2}{*}{\multicolumn{2}{|c|}{$\begin{array}{r}\text { clast }(n=14) \\
s d\end{array}$}} & \multicolumn{2}{|c|}{$\operatorname{vein}(n=5)$} & \multicolumn{2}{|c|}{$\operatorname{clast}(n=28)$} & \multicolumn{2}{|c|}{$\operatorname{vein}(n=4)$} \\
\hline & & & & $s d$ & & $s d$ & & $s d$ \\
\hline $\mathrm{SiO}_{2}$ & $<0.01$ & & 0.04 & 0.02 & 0.21 & 0.10 & 0.02 & 0.01 \\
\hline $\mathrm{TiO}_{2}$ & $<0.01$ & & $<0.01$ & & 0.02 & 0.02 & 0.03 & 0.03 \\
\hline $\mathrm{Al}_{2} \mathrm{O}_{3}$ & $<0.01$ & & $<0.01$ & & 0.01 & 0.01 & 0.01 & 0.01 \\
\hline FeO & $<0.01$ & & $<0.01$ & & 0.17 & 0.10 & 0.02 & 0.01 \\
\hline MnO & 0.06 & 0.04 & $<0.01$ & & 0.20 & 0.12 & 0.10 & 0.09 \\
\hline MgO & 0.02 & 0.01 & 0.54 & 0.22 & 0.51 & 0.35 & 0.31 & 0.18 \\
\hline $\mathrm{CaO}$ & 54.87 & 2.54 & 54.42 & 0.61 & 56.02 & 3.58 & 56.41 & 1.74 \\
\hline $\mathrm{Na}_{2} \mathrm{O}$ & 0.01 & 0.01 & $<0.01$ & & 0.02 & 0.01 & 0.02 & 0.02 \\
\hline $\mathbf{K}_{2} \mathbf{O}$ & $<0.01$ & & $<0.01$ & & $<0.01$ & & $<0.01$ & \\
\hline \multirow[t]{2}{*}{ Total } & 54.96 & & 55.00 & & 57.15 & & 56.91 & \\
\hline & \multicolumn{2}{|c|}{$n=14$} & \multicolumn{2}{|c|}{$n=5$} & \multicolumn{2}{|c|}{$n=2$} & \multicolumn{2}{|c|}{$n=7$} \\
\hline $\mathbf{L i}$ & 0.75 & 0.47 & 0.39 & 0.02 & 0.094 & 0.030 & 0.45 & 0.09 \\
\hline B & 0.48 & & 0.55 & & 0.14 & 0.05 & 0.93 & 0.05 \\
\hline Sc & 0.44 & 0.33 & 0.30 & 0.21 & 0.069 & 0.008 & 1.6 & 0.1 \\
\hline $\mathbf{V}$ & 0.44 & 0.34 & 0.20 & & 0.009 & 0.005 & 0.82 & 0.40 \\
\hline $\mathrm{Cr}$ & 6.6 & 2.8 & 2.7 & 1.9 & 1.9 & 0.2 & 11 & 6 \\
\hline Co & 1.2 & 2.1 & 0.27 & 0.27 & 0.21 & 0.14 & 4.7 & 1.8 \\
\hline $\mathbf{N i}$ & 36 & 19 & 11 & 6 & 4.4 & 2.7 & 320 & 150 \\
\hline $\mathbf{Z n}$ & 0.95 & 0.45 & 0.16 & 0.09 & 0.26 & 0.13 & 7.8 & 3.0 \\
\hline As & $<0.014$ & & 0.083 & 0.108 & 0.021 & 0.010 & 0.092 & \\
\hline $\mathbf{R b}$ & 0.023 & 0.012 & $<0.007$ & & 0.006 & 0.002 & 0.024 & 0.008 \\
\hline $\mathbf{S r}$ & 89 & 26 & 160 & 80 & 120 & 50 & 120 & 10 \\
\hline $\mathbf{Y}$ & 0.42 & 0.62 & 0.25 & 0.22 & 0.009 & 0.004 & 0.12 & 0.02 \\
\hline $\mathbf{Z r}$ & $<0.008$ & & 0.010 & & $<0.027$ & & $<0.001$ & \\
\hline $\mathbf{N b}$ & $<0.005$ & & $<0.004$ & & $<0.003$ & & $<0.002$ & \\
\hline In & $<0.004$ & & $<0.003$ & & $<0.014$ & & $<0.014$ & \\
\hline $\mathbf{S b}$ & $<0.020$ & & $<0.017$ & & $<0.075$ & & $<0.003$ & \\
\hline Cs & $<0.004$ & & $<0.004$ & & 0.026 & 0.011 & 0.026 & 0.011 \\
\hline $\mathbf{B a}$ & 0.36 & 0.18 & 0.39 & 0.35 & 1.5 & 1.1 & 1.2 & 0.3 \\
\hline $\mathbf{L a}$ & 0.014 & & 0.012 & & 0.004 & 0.002 & 0.019 & \\
\hline $\mathrm{Ce}$ & 0.012 & 0.007 & 0.007 & & 0.015 & 0.001 & 0.015 & 0.001 \\
\hline Pr & 0.011 & & $<0.003$ & & 0.001 & & $<0.001$ & \\
\hline Nd & 0.056 & & 0.025 & & $<0.039$ & & $<0.014$ & \\
\hline $\mathrm{Sm}$ & 0.076 & 0.047 & 0.062 & & 0.004 & & $<0.018$ & \\
\hline Eu & 0.026 & & 0.010 & & 0.002 & & $<0.003$ & \\
\hline Gd & 0.15 & 0.15 & 0.040 & & $<0.037$ & & $<0.013$ & \\
\hline $\mathbf{T b}$ & 0.053 & & 0.008 & & $<0.006$ & & $<0.001$ & \\
\hline Dy & 0.13 & 0.16 & 0.029 & 0.004 & $<0.020$ & & $<0.007$ & \\
\hline Ho & 0.045 & 0.048 & 0.013 & 0.003 & 0.001 & & $<0.001$ & \\
\hline $\mathbf{E r}$ & 0.16 & 0.15 & 0.044 & 0.019 & $<0.023$ & & $<0.010$ & \\
\hline Tm & 0.047 & & 0.007 & 0.001 & $<0.006$ & & $<0.001$ & \\
\hline
\end{tabular}




\section{Click here to download Table: Table_4_rev.xlsx}

Table 4. Whole-rock C-O and Sr isotopic composition for serpentinite, limestone and ophicarbonate rocks

\begin{tabular}{|c|c|c|c|c|c|c|c|c|c|c|}
\hline & & \multirow{3}{*}{$\frac{\delta^{18} \mathbf{O}(\mathbf{\% o})}{n . d .}$} & \multirow{3}{*}{$\frac{\delta^{13} \mathbf{C}(\mathbf{( \% )})}{n . d .}$} & \multirow{3}{*}{$\frac{\mathbf{R b} / \mathbf{S r}}{-}$} & \multirow{3}{*}{$\frac{{ }^{87} \mathbf{S r}{ }^{86} \mathbf{S r}}{0.706929}$} & \multirow{3}{*}{$\frac{\text { err }}{0.000038}$} & \multicolumn{2}{|l|}{ Jurassic age } & \multicolumn{2}{|l|}{ High-pressure age } \\
\hline \multirow{4}{*}{$\begin{array}{l}\text { Oc. serp. } \\
\text { Limestone }\end{array}$} & \multirow{3}{*}{$\begin{array}{r}\text { MNT 15-1 } \\
\text { ZRL 15-7 }\end{array}$} & & & & & & ${ }^{87} \mathrm{Sr}^{86} \mathrm{Sr}_{160 \mathrm{Ma}}$ & $\begin{array}{l}\Delta \text { (measured- } \\
160 \mathrm{Ma} \text { ) }\end{array}$ & ${ }^{87} \mathrm{Sr} /{ }^{86} \mathrm{Sr}_{33 \mathrm{Ma}}$ & $\begin{array}{c}\Delta \text { (measured- } \\
\text { 33Ma) }\end{array}$ \\
\hline & & & & & & & 0.706929 & 0.000000 & & \\
\hline & & 26.1 & 0.5 & 0.0128 & 0.707932 & 0.000009 & 0.707848 & 0.000084 & & \\
\hline & MNT 13-5 & 10.9 & 1.4 & 0.0048 & 0.706355 & 0.000007 & 0.706323 & 0.000032 & & \\
\hline \multirow{3}{*}{$\begin{array}{l}\text { OCI (tectonic } \\
\text { ophic.) }\end{array}$} & ZRL 13-1 & 15.7 & 0.6 & 0.0009 & 0.706162 & 0.000009 & 0.706156 & 0.000006 & & \\
\hline & ZRL 15-3 & 15.6 & 1.1 & 0.0099 & 0.706768 & 0.000016 & 0.706703 & 0.000065 & & \\
\hline & ISC 13-1 & 16.2 & 0.4 & 0.0020 & 0.706510 & 0.000012 & 0.706497 & 0.000013 & & \\
\hline \multirow{4}{*}{$\begin{array}{c}\text { OCII (sedimentary } \\
\text { ophic.) }\end{array}$} & SG 15-4 & 17.4 & 1.1 & 0.0143 & 0.705756 & 0.000009 & 0.705662 & 0.000094 & & \\
\hline & SG 15-2 & 15.9 & -1.7 & 0.0015 & 0.706046 & 0.000022 & 0.706036 & 0.000010 & & \\
\hline & MNT 15-2 & 17.0 & 1.6 & 0.0023 & 0.706790 & 0.000009 & 0.706775 & 0.000015 & & \\
\hline & PL 13-1 & 15.1 & 0.3 & 0.0007 & 0.706624 & 0.000008 & 0.706619 & 0.000005 & & \\
\hline Prograde & PL 13-2 & 15.3 & 0.2 & 0.0005 & 0.706833 & 0.000009 & 0.706830 & 0.000003 & & \\
\hline \multirow[t]{3}{*}{ ophicarbonates } & CU 3 & 17.7 & -0.3 & 0.0009 & 0.706383 & 0.000008 & 0.706377 & 0.000006 & & \\
\hline & CU 13-1 & 17.1 & -2.8 & 0.0005 & 0.707530 & 0.000009 & 0.707527 & 0.000003 & & \\
\hline & SA $15-1_{\text {calcite }}$ & 12.5 & 1.0 & $<0.0001$ & 0.707969 & 0.000014 & 0.707969 & 0.000000 & 0.707969 & 0.000000 \\
\hline \multirow{4}{*}{$\begin{array}{c}\text { Eclogite facies } \\
\text { ophicarbonates }\end{array}$} & SA 15-1 dolomite & 11.9 & 0.8 & 0.0001 & 0.708130 & 0.000022 & 0.708130 & 0.000000 & 0.708130 & 0.000000 \\
\hline & SA 15-8 & 11.5 & 0.4 & 0.0013 & 0.709670 & 0.000009 & 0.709661 & 0.000009 & 0.709668 & 0.000002 \\
\hline & LP13 EOC1 & 11.3 & 0.7 & 0.0011 & 0.708453 & 0.000005 & 0.708446 & 0.000007 & 0.708452 & 0.000001 \\
\hline & LP13 EOC3 & 15.0 & 0.5 & 0.0006 & 0.706791 & 0.000010 & 0.706787 & 0.000004 & 0.706790 & 0.000001 \\
\hline
\end{tabular}


Supplementary Table A1
Click here to download Background dataset for online publication only: Supplementary-Table-A1.xlsx 
Supplementary Table A2
Click here to download Background dataset for online publication only: Supplementary-Table-A2.xIsx

Supplementary Table A2
Click here to download Background dataset for online publication only: Supplementary-Table-A2.xIsx 
Supplementary Table A3
Click here to download Background dataset for online publication only: Supplementary-Table-A3.xIs

Supplementary Table A3
Click here to download Background dataset for online publication only: Supplementary-Table-A3.xIs

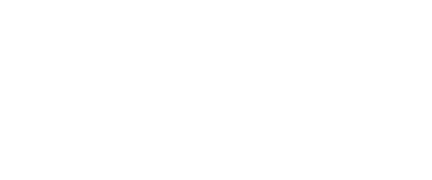

che

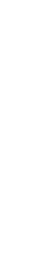
. . . . . . . . . . . 

Appendix Figure A1
Click here to downlo

Click here to download Background dataset for online publication only: Appendix_Figure_A1.jpg 
Supplementary material S1
Click here to download Back

Click here to download Background dataset for online publication only: Supplementary_material_S1.docx

(

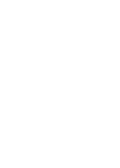

(1)

(1)

西

.

.

.

.

.

.

.

.

.

.

.

.

.

.

.

.

.

.

.

.

.

.

.

.

.

.

.

.

.

.

.

. 